\title{
Explaining Political Regime Diversity \\ In Post-Communist States: \\ An Evaluation and Critique of Current Theories
}

\author{
Simeon Mitropolitski \\ Department of Political Science \\ McGill University, Montreal \\ February 2007
} A thesis submitted to McGill University in partial fulfillment of the requirements of the
degree of Master of Arts

(C) Simeon Mitropolitski 2007 


$\begin{array}{ll}\begin{array}{l}\text { Library and } \\ \text { Archives Canada }\end{array} & \begin{array}{l}\text { Bibliothèque et } \\ \text { Archives Canada }\end{array} \\ \begin{array}{l}\text { Published Heritage } \\ \text { Branch }\end{array} & \begin{array}{l}\text { Direction du } \\ \text { Patrimoine de l'édition }\end{array} \\ \begin{array}{l}\text { 395 Wellington Street } \\ \text { Ottawa ON K1A 0N4 }\end{array} & \begin{array}{l}\text { 395, rue Wellington } \\ \text { Ottawa ON K1A ON4 } \\ \text { Canada }\end{array} \\ \end{array}$

Your file Votre référence ISBN: 978-0-494-32538-4 Ourfile Notre référence ISBN: 978-0-494-32538-4

NOTICE:

The author has granted a nonexclusive license allowing Library and Archives Canada to reproduce, publish, archive, preserve, conserve, communicate to the public by telecommunication or on the Internet, loan, distribute and sell theses worldwide, for commercial or noncommercial purposes, in microform, paper, electronic and/or any other formats.

The author retains copyright ownership and moral rights in this thesis. Neither the thesis nor substantial extracts from it may be printed or otherwise reproduced without the author's permission.
AVIS:

L'auteur a accordé une licence non exclusive permettant à la Bibliothèque et Archives Canada de reproduire, publier, archiver, sauvegarder, conserver, transmettre au public par télécommunication ou par l'Internet, prêter, distribuer et vendre des thèses partout dans le monde, à des fins commerciales ou autres, sur support microforme, papier, électronique et/ou autres formats.

L'auteur conserve la propriété du droit d'auteur et des droits moraux qui protège cette thèse. $\mathrm{Ni}$ la thèse ni des extraits substantiels de celle-ci ne doivent être imprimés ou autrement reproduits sans son autorisation.
In compliance with the Canadian Privacy Act some supporting forms may have been removed from this thesis.

While these forms may be included in the document page count, their removal does not represent any loss of content from the thesis.
Conformément à la loi canadienne sur la protection de la vie privée, quelques formulaires secondaires ont été enlevés de cette thèse.

Bien que ces formulaires aient inclus dans la pagination, il n'y aura aucun contenu manquant. 


\begin{abstract}
This study seeks to assess theories of post-communist political regime diversity. Since 1989 tens of former communist countries in Central and Eastern Europe and in the ex-Soviet Union developed into a rainbow of regimes, from stable democracies to stable autocracies. Four major theoretical approaches attempt to explain this diversity by focusing respectively on legacies, institutional choices, political leadership, and external influence. These approaches are tested using a sample of three post-communist countries representing different political trajectories: democracy, authoritarianism, and intermediate regimes. This study finds that none of these approaches comprehensively explains this diversity. "Unpacking" these approaches, however, and combining some elements from each, provides a good starting point for understanding the problem. Designing particular institutions like an electoral system and a strong presidential office may produce democratic or authoritarian trends. Particular legacies such as lack of shared public identity between rulers and the ruled can interfere and, despite institutional preconditions, keep post-communist countries in an intermediate regime position.
\end{abstract}

\title{
RÉSUMÉ
}

Cette étude cherche à évaluer des théories sur la diversité des régimes politiques dans des pays ex-communiste. Depuis 1989 dizaines de pays dans l'Europe Centrale et Orientale et dans l'ex-URSS ont développé dans un arc-en-ciel de régimes, allant des démocraties aux autocraties. Quatre approches théoriques essaient d'expliquer cette diversité par l'héritage, les choix institutionnels, la direction politique, et l'influence externe. Ces approches sont testées sur un échantillon de trois pays ex-communistes représentant des trajectoires différentes, la démocratie, l'autoritarisme, et le régime intermédiaire. Les conclusions montrent qu'aucun de ces approches n'explique pas completment cette diversité. Le "déballage" de ces approches et la combinaison des éléments à travers elles fournit cependant un bon point de départ pour comprendre le problème. Concevoir des institutions politique particulière peut produire des tendances démocratiques ou autoritaires. Les héritages particuliers peuvent interférer et, malgré les bonnes conditions institutionnelles, garder des pays ex-communistes dans une situation politique intermédiaire. 


\section{ACKNOWLEDGEMENTS}

Completion of this project would not have been possible without the support and patience that was given so generously by those who made this fascinating journey with me. I would like to thank especially Professor Juliet Johnson, my advisor. She was always ready to listen my proposals, always ready to make necessary comments, and always ready suggesting new directions and thus to help me grow as a researcher. I would also like to thank Professors Philip Oxhorn and Hudson Meadwell for their useful feedback and countless improvements suggested while this project was still a mere proposal. They all helped me to make it clearer and thus facilitated my undertaking. I want to thank the Government of Quebec for providing financial assistance necessary for completing this project.

I want to thank my family, my wife Nevena, daughter Elitza, and son Lubomir, for their total understanding and patience throughout this long and winding journey. I wholeheartedly dedicate this project to them. 


\section{Table of contents}

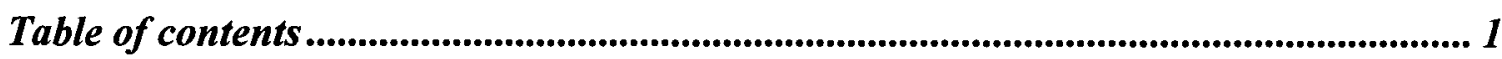

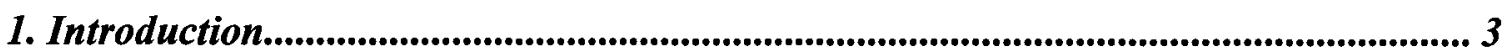

1.1. The problem of post-communist regime diversity .......................................... 3

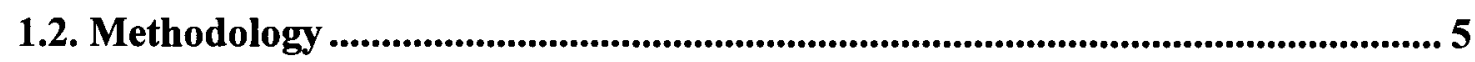

1.3. Organization ................................................................................................................... 11

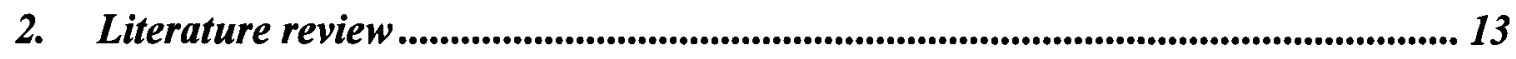

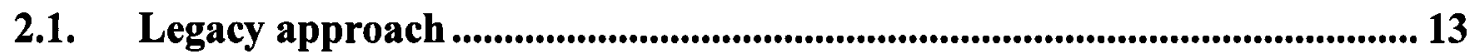

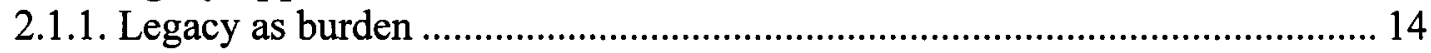

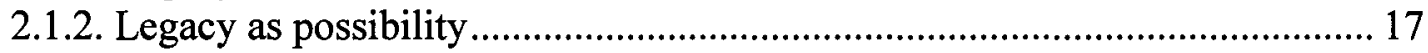

2.2. Institutional choice approach .................................................................. 20

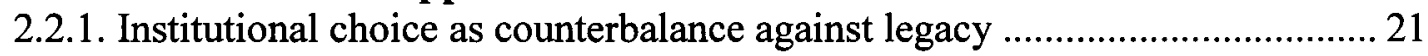

2.2.2. Institutional choice threatening democratization ...................................... 23

2.3. Political leadership approach.................................................................................. 25

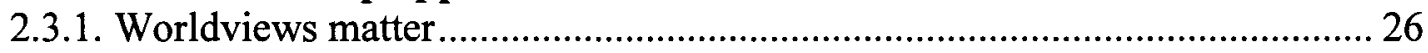

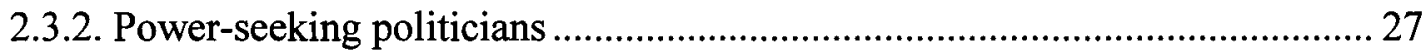

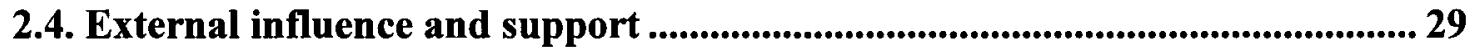

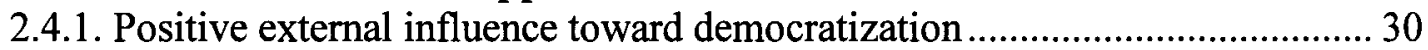

2.4.2. Mixed or negative external effect on democratization ............................... 31

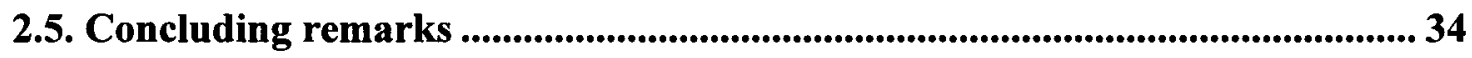

3. Generic models.................................................................................................... 35

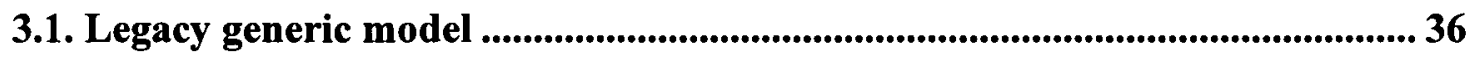

3.2. Institutional choice generic model............................................................. 39

3.3. Political leadership generic model ........................................................................ 42

3.4. External influence and support generic model .................................................. 44

3.5. Concluding remarks ....................................................................................................... 47

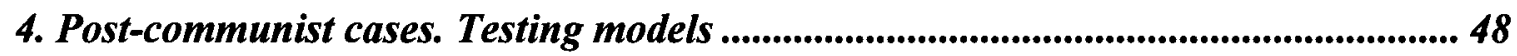

4.1. Romania. General information................................................................................ 48

4.2. Belarus. General information ............................................................................ 50

4.3. Macedonia. General information .............................................................5

4.4. Testing the legacy model ........................................................................................... 52

4.5. Testing the institutional choice model........................................................... 61

4.6. Testing the political leadership model .................................................................. 66 
4.7. Testing the external influence model.............................................................. 70

4.8. Concluding remarks ................................................................................................. 75

5. Discussing findings. Building flexible cross-model explanation ................................ 78

5.1. Impossibility of establishing rigid cross-models explanation ........................... 79

5.2. Tentative attempts of establishing flexible cross-model explanation ............... 83

5.3. Concluding remarks ............................................................................................. 89

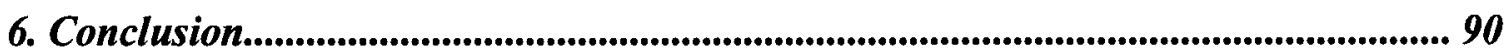

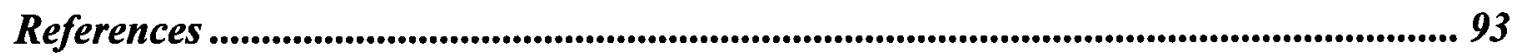




\section{Introduction}

\subsection{The problem of post-communist regime diversity}

Between 1989 and 2006, tens of former communist countries in Central and Eastern Europe and in the former Soviet Union developed into a rainbow of different political regimes, from stable democracies to stable authoritarianisms through intermediate and unconsolidated regimes. This process of post-communist transition and political diversification began almost simultaneously in all of these regions after 1989. Several theoretical models attempt to explain this diversity, embracing cases as diverse as Hungary's ${ }^{1}$ almost immediate and successful democratization in the early 1990s to Turkmenistan's persistently undemocratic political regime up to late 2006. Existing theories focus on independent variables representing four major analytical categories: legacies, institutional choices, political leadership, and external influence. These categories look at politically relevant events taking place before, during and after communism, factors that are deeper or shallower in terms of causality, and also more structural or agencyoriented. They all claim to possess explanatory power regarding post-communist political regime diversity.

This project puts forward the following objectives: It will analytically separate the major schools of post-communist political regime development and regime diversity in the literature and provide typical examples for each of them. It will then draw upon existing research in each category to craft generic theories, outlining basic hypotheses and assumptions common to researchers within each category ${ }^{2}$.

Once this task is accomplished and generic theories are crafted, the project will evaluate them, testing their explanatory claims on a sample of post-communist countries representing different regime trajectories: democracy, authoritarianism, and intermediate political regimes. Countries included in this sample are Romania

\footnotetext{
${ }^{1}$ Freedom House Organization. 2006. "Freedom in the World Comparative Ranking: 1973-2005". Available on: http://www.freedomhouse.org/

${ }^{2}$ I would like to thank Prof. Philip Oxhorn for suggesting this methodological approach of crafting generic theories in order to facilitate project design.
} 
(democracy), Belarus (authoritarianism), and Macedonia (intermediate regime), not only illustrating different political trajectories, but also different post-communist geographic areas: Eastern Europe, the former USSR, and former Yugoslavia. Finally, this project aims to begin addressing problems of incomplete explanation existing with the current research by suggesting a new model that bridges these approaches.

This project advances the following main points and provides the following tentative conclusions. First, none of the existing major analytical categories taken as a cluster is powerful enough to predict all the major trends of post-communist regime diversity. Contrary to the claims they advance, their cumulative prediction is either inconclusive, or points in the wrong direction. Second, 'unpacking' these analytical categories into a myriad of independent variables does not solve the problem. Only a few of them correlate well with one or another post-communist period across all cases. None of these is powerful enough to provide a rigid explanatory model of political regime development that goes beyond simple correlation. Third, two independent variables provided by the institutional choice approach, namely the constitutional separation of powers and the electoral system for parliament (i.e. proportional representation vs. single-member district) do provide good correlation and explanation for opposing trends of political regime development, democracy or authoritarianism. Fourth, additional independent variables included in the legacy and institutional choice approaches, namely shared public identity between rulers and the ruled, and the existence of a sovereign state, provide an additional insight as to the reason why certain post-communist countries still remain intermediate regimes. Fifth, this new explanatory model is applicable mainly to post-communist development after the mid-1990s; it does not claim to provide a satisfactory explanation of trends occurring earlier in the post-communist transition process. Understanding post-communist development and diversity is a gradual process, not an instant snapshot; new advances in the literature will hopefully provide additional hypotheses and independent variables, within or outside the existing schools, making further analysis more accurate and its conclusions more rigid. 


\subsection{Methodology}

The project's methodology is as follows: first, it will offer a comprehensive review of the literature, which is used to craft generic theories representing four different theoretical approaches that claim to explain post-communist regime diversity; second, it will define the dependent variable of political regime, and choose representative cases from among post-communist countries with different political regimes; third, it will test generic theories using the chosen sample; and fourth, it will craft a new model that provides tentative explanation for political regime diversity.

A comprehensive review of the literature is a necessary first step in all research, but in the context of this project its significance is even greater. The goal is not only to present earlier research on the topic of post-communist political regime diversity, but also to select different explanations as part of four larger approaches: legacies, institutional choices, political leadership, and the extent of external influence and support. These main approaches borrow from earlier research and classification presented by Kitschelt $(2003,57-58)$. This project presents the major arguments and expectations of each particular approach regarding postcommunist political development. Each independent variable from each theoretical model is presented in "if-then" form, when "then" is specific post-communist political regime type.

Once earlier research and its expectations are presented and classified, the main task becomes to craft generic models, one out of each theoretical approach. These four models represent simplified constructs showing basic and mutually reinforcing features of particular theoretical approaches and their expectations regarding post-communist political regime development. The purpose of crafting generic models is to simplify the project design in order to allow it to focus on as few as possible comparable models, instead of tens of incomparable hypotheses. Without this simplification, the whole project might have become unmanageable. An alternative way of simplifying the thesis design would have been to choose only one particular work within each approach as fully representative. This, however, 
would have led to unjust elimination of some important variables explaining a small but important part of the main problem.

Even after deciding not to eliminate most independent variables there are different ways of crafting generic models. A more deterministic approach expects that all variables within one particular model, e.g. legacies, must concur in order to cause particular political development. An alternative and more flexible approach, such as employed in this project, is to accept that the independent variables are not causing each other but rather contribute to regime-type diversity. Crafting generic models constitutes an initial filter of the independent variables, leaving behind the weak ones that are not easily observable and measurable. Other variables not included in the four basic models are those implying many different meanings, e.g. culture. At this point some independent variables may be conceptually split between different models. One good example of a variable that represents more than one analytical concept is the communist party. It is part of the communist legacy and at the same time part of the political system after the collapse of communism in most post-communist countries.

After we craft four generic models, the next logical step is to look more closely at post-communist political regime development, to define the political regime itself, and to choose cases representing different regime trajectories. We define political regime as a set of political institutions, formal as well as informal, by which a state is organized in order to exert its power over a political community (Kopstein and Lichbach 2005, 4). Political regime types depend on the level of citizens' political rights and of popular influence on government. Political regimes are democratic, authoritarian, or intermediate. Political regime as the dependent variable is measured using Freedom House's (Freedom House 2005) classification of countries from 1 (most democratic) to 7 (least democratic) dependant on their level of freedom, using its combined index, representing an average of political rights and civil liberties in each post-communist country (Table 1).

Democratic regimes always practice free and fair elections; elected officials effectively rule; minority groups can participate in government; and basic civil liberties, including freedom of expression, assembly, association, education, and 
religion, are protected. Authoritarian regimes deny their citizens most political and social rights; these regimes are based on oppression and fear. Intermediate regimes are those with intensive civil and unconstitutional political conflicts; elections are unfair, giving dominance to one political party or leader; some civil liberties are either suppressed or are not enforced.

This study does not question the reliability of Freedom House methodology, nor does it duplicate its research design and execution to verify the accuracy of its findings regarding post-communist countries. The author trusts these findings, which are supported both by numerous researchers through integration in their studies (Roeder 2001; Frye 2002; Grzymala-Busse 2006), and by independent projects like the Polity IV Project (2003), which confirm main post-communist political trends.

This project, however, does make a special effort to eliminate the danger of conflating independent variables, i.e. possible explanations for regime diversity, and the dependent variable, which is political regime itself. To do this, each variable, before being included in any generic model, will be preliminarily reviewed, taking into account Freedom House definitions for each type of political regime. In this sense, hypothetically speaking, freedom of expression will not be allowed as an independent variable, because it is conceptually included in the dependent variable's definition; on the other hand, specific religious background will be allowed as a possible independent variable because it is independent from political regime definition.

In this project $\mathrm{I}$ accept that those post-communist countries rated by Freedom House as 'free' represent democratic political regimes; those rated as 'not free' represent authoritarian regimes; and 'partly free' represent intermediate political regimes. Also post-communist countries moving within a limited range on the Freedom House scale over time represent more stable political regimes, no matter their nature.

The next logical step is to determine which post-communist countries best represent each political regime trajectory. We must eliminate overdetermined cases of political development like Hungary or Turkmenistan, countries where 
democratization either occurs overnight or does not occur at all, thus leaving for investigation only countries where the situation in the early 1990s is described by Freedom House as 'partly free', leaving the door open for democratization, authoritarian reaction, or for keeping the country in the intermediate position. Elimination of overdetermined cases is necessary because for them most independent variables look convincing, but this overconfidence is in fact more a problem than a solution because it does not differentiate between good causes and spurious correlations.

There are many post-communist countries that fit well with initial 'partly free' status, both from Eastern Europe and the former Soviet Union (Table 1). Countries like Albania, Armenia, Georgia, Macedonia, Moldova, and Ukraine remain 'partly free' for the entire post-communist period, up until 2005 Freedom House report. Putting aside countries that democratize within months or a year in early 1990 s, there are two remaining cases that represent gradual democratization from 'partly free' to stable 'free' status, Croatia and Romania. Cases representing the opposite trend, reaching stable and 'not free' status, putting aside those moving to authoritarianism very fast within months or a year in the early 1990s, are Belarus and Kazakhstan. Russia also moves to 'not free' status, but it is too early to call it a stable autocracy, and therefore it will not be considered a good example of the authoritarian trend.

The sample that is tested includes only one case from each group because of the time and space restraints of the project. From the first group of stable 'partly free' countries Macedonia is most representative. The reason for this is that it moving within the smallest margins over time compared to other stable intermediate political regimes. From the second group of countries moving from 'partly free' to 'free' status Romania is the best choice. The reason for this is that it moves to a level of freedom similar to Croatia, starting from much worse position, i.e. its political democratization is more spectacular over time. From the third group moving from 'partly free' to 'not free' status I choose Belarus. The reason for this is that it reaches a higher level on the scale of lack of freedom than Kazakhstan after starting from a much better position in the early 1990s, and also because 
Belarus experiences 'partial freedom' for a longer period than Kazakhstan. The difference between Macedonia and Romania may not look spectacular for the last year of observation (0.5), but over a longer period, since Romania shifts from 'partly free' to 'free' status, the difference between the two countries rises to 1.2 (2.1 for Romania and 3.3 for Macedonia).

Having a sample including these three countries, representing at the same time the former Soviet Union, Eastern Europe and the former Yugoslavia, makes any conclusion of this study fitter for generalization across post-communist countries. Countries that are eliminated from the sample, like Croatia, Kazakhstan, Albania, Moldova, Armenia, and Georgia, are used at the end of project as control group for testing a new model that explains political regime diversity.

After identifying these three countries, four generic models are tested separately on each of them. At this point, I conclude that all four models make unsatisfactory predictions regarding post-communist political regime diversity, ranging from inconclusive to completely wrong. At best, but still far from providing a comprehensive answer to the main research problem, some of these models make correct predictions for some countries and for shorter periods.

Being unsatisfied with previous answers to the main problem, this project crafts a new model with greater explanatory power. It takes an initially "unpacked" independent variable across different models proving in such a way that their weak predictive power is not due to their cumulative effect. Even separately most of them do not correctly predict different political trends across cases. Additional analysis shows that this problem has little to do with the fact that some variables may be designed to explain opposite political developments, like democracy and authoritarianism, much better than intermediate regimes.

"Unpacking" independent variables however represents a good opportunity for trying to combine elements across models correlating well with different postcommunist trajectories. I discuss two possible approaches, one more rigid and one more flexible. The rigid model is finally abandoned because few remaining variables, usually taken from the legacy model, contradict their proper logic by providing positive correlations only after a certain time lag without good 
Table 1. Freedom House's 'Freedom in the World Comparative Rankings' (excerpts)

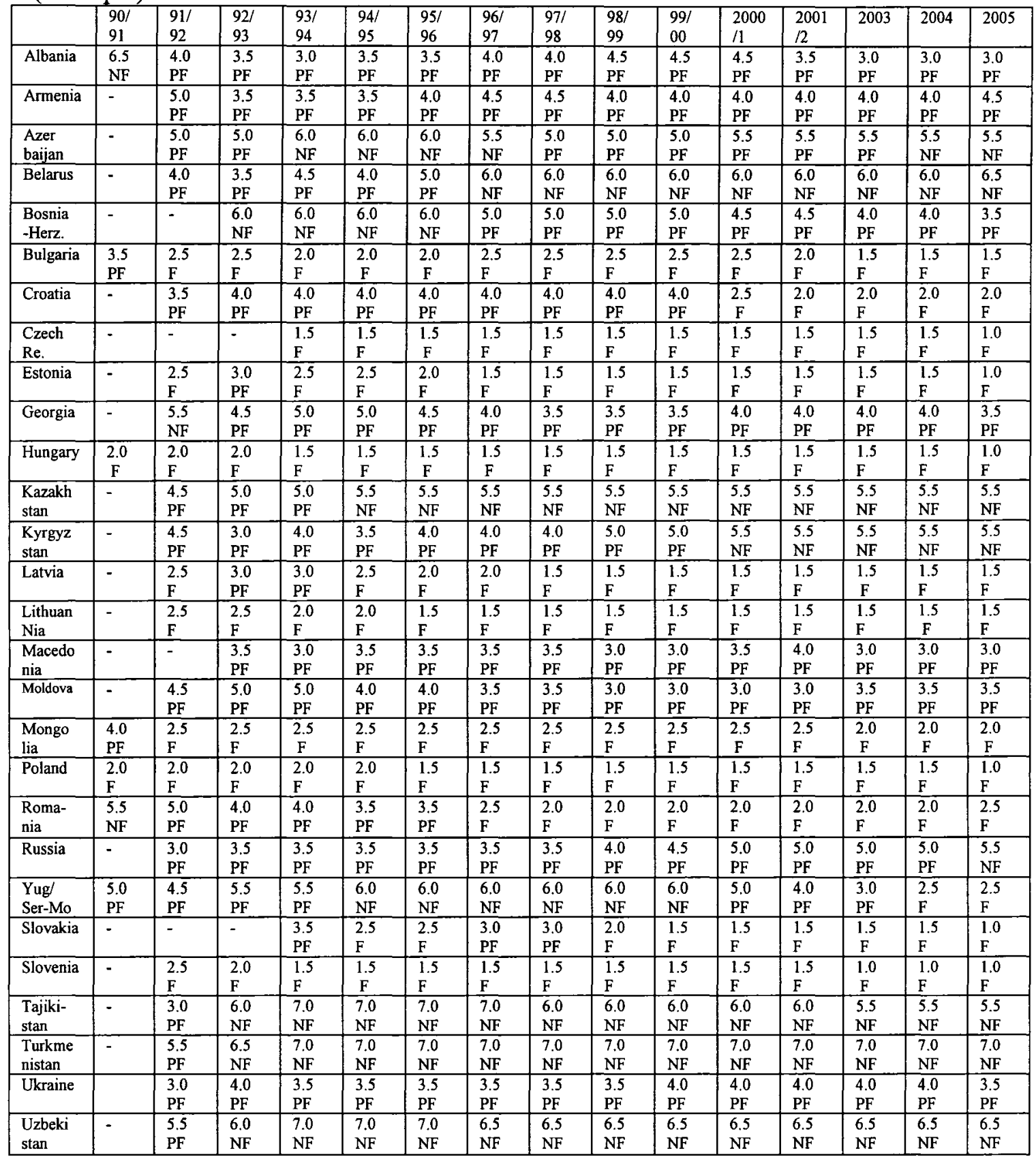

Source: Freedom House Organization. 2006. Available online: http://www.freedomhouse.org/ Legend: NF-Not free; PF - Partly Free; F- Free. 
explanation for these counterintuitive outcomes. A second-best option is crafting a more flexible two-stage model, by looking first at across various models' explanations for opposite democracy-authoritarianism trends, and only then adding missing variables that explain intermediate regimes. This more flexible new model explains opposite regime trends mainly through certain institutional arrangements during post-communist transition, like constitutional separation of powers and electoral system for legislature. They produce political outcomes, democracy or authoritarianism, after a certain time lag. Other factors, from legacy and institutional models alike, like existence of sovereign state and shared identity between rulers and ruled, provide convincing explanation for intermediate postcommunist regime trajectory.

\subsection{Organization}

The project's organization closely follows its main scientific problem and methodology. After this introduction that lays out the project's foundation, chapter 2 provides a review of the literature. The literature used for analysis in this project is readily available in either hard copies or in online versions. It covers research published between the early 1990s and 2006. I rely mainly on English-language books and on articles from English-language political and other social science journals; occasionally I rely also on French- and Russian-language research and on public opinion poll results. Alongside literature that deals with post-communist transition, this review extensively borrows ideas from seminal books on democratization and comparative political development, e.g. Crawford and Lijphart (1997) or Linz and Stepan (1996), to mention a few.

The next chapters present the theoretical part of this project. They consecutively offer generic models crafted out of four main approaches: legacies, institutional choices, political leadership, and external influence (chapter 3); test these four models to three cases representing different political regime trajectories (chapter 4); and offer new tentative model explaining post-communist regime diversity (chapter 5). In conclusion, I make a summary of the main findings of this 
project and present questions generated by it that may form a basis for new research.

Interest in understanding post-communist countries' political transformation and their possible democratization goes far beyond the group of current postcommunist nations, for some of which the process of democratization is firmly an issue of the past. Some countries in the world still remain communist as far as their political system is concerned, not to mention tens of countries with different forms of undemocratic or unconsolidated political regimes. Although unable to predict speed, direction and starting moment of their future post-authoritarian political transformations, we may use lessons accumulated during the 1989-2006 experience in Central and Eastern Europe and the former USSR in order to prepare for a range of possible expectations and a menu of political suggestions as to how to make these democratic transitions smoother and hopefully irreversible. This suggests that research into the causes of post-communist political regime diversity has a promising future as a sub-field of comparative democratization studies. 


\section{Literature review}

Many scholars have tried to explain post-communist political regime diversity, either in general or in particular countries. Four broader groups of theoretical approaches, following Kitschelt's classification (2003, 57-58), focus on the following groups of factors: legacies, institutional choices, political leadership, and extent of external influence and support. This chapter reviews these groups' major arguments and expectations regarding post-communist democratization. Presenting the literature on the main subject of research is a necessary first step toward crafting generic theoretical models of post-communist regime change, one for each broader group of explanations; presenting these generic models will be the next chapter's task.

\subsection{Legacy approach}

Legacy approach, chronologically the oldest school of post-communist democratization studies, tends to explain political regime diversity by the unique historical experience of each country. Differences in its past generate the differences we can currently observe. This school looks at politically relevant events and processes, which may be political, social, economic, and religious practices or norms, accumulated during pre-communist and/or communist period. Compared to other main schools of post-communist democratization studies, the legacies approach explanation presents the 'deepest' theoretical argument in terms of causality, according to Kitschelt's classification (2003). He makes a distinction between "deep" and "shallow" explanations; the first type establishes clear temporal priority of the cause vis-à-vis the consequence, and independence of the cause from its effect; the latter is far less precise on both issues. The trade-off is that it is far more difficult for the "deep" explanations to prove that there is a real causeeffect relation and not just a positive correlation between independent and dependent variable.

The legacy approach is not a static model; some of its supporters gradually move from the understanding that legacies act always as a burden for 
democratization (Jowitt 1992) to a more balanced view according to which at least some legacies may have a positive impact on democratization (Kitschelt, Mansfeldova, Markowski, and Toka 1999).

There are two main streams within the school looking at legacies as main causes for post-communist political development. One of these sees legacies as a burden for democratization; in this sense a process of democratization is a process that eliminates these legacies from political life. Another stream sees legacies as a possible avenue toward democratization (see 2.1.2. Legacies as possibility). Some of those who see legacies as a burden make bleak predictions of post-communist democratization (Jowitt 1992; Schopflin 1993). Other scholars, however, try to overcome this fatalism and have a more optimistic view for at least some postcommunist countries. They either look at pre-communist legacies as being able to eliminate the negative effect of communist era legacies (Brzezinski 2002), or point out at the gradual process of erosion of communist legacies in post-communist societies (Hanson 1995; 1997).

\subsubsection{Legacy as burden}

Jowitt (1992) argues that communist era legacies matter most and that they are a burden for democratization; they instead favor authoritarian political trends. Communist legacies, according to Jowitt, include reinforced dichotomy between public and private areas, low levels of political participation, lack of shared civic identity, social atomization and the presence of semi-autarchic economic institutions like cooperative farms (Jowitt 1992, 287-289). In addition to this many post-communist countries bear deep ethnic and territorial fragmentations, some inherited from pre-communist times. The cumulative effect of all these legacies plays a negative role in the post-communist process of democratization. Therefore countries where some of these legacies are weakest for historic reasons, like Poland, where widespread collective farming is missing for most of the communist era, or Yugoslavia, which practices market socialism, have only slightly better chances for political development as democratic regimes. 
Jowitt is very pessimistic regarding the possibility of political democratization in post-communist world in general. These countries will not copy Western Europe's political present, their political development is more likely to resemble Latin America's authoritarian past. It will be demagogues, priests, and colonels more than democrats and capitalists who will shape post-communist countries' general institutional identity (Jowitt 1992, 300). As a better alternative to religio-ethnic, militant nationalist, or even fascist regimes, he suggests a form of liberal authoritarianism like nineteenth-century Western Europe (Jowitt 1992, 303).

Schopflin (1993) shares Jowitt's view that legacies matter most in postcommunist political regime development. He also shares Jowitt's view that these legacies are a burden for democratization, and that they instead favor authoritarian trends. His model enlarges the time framework of the legacy approach by including pre-communist legacies as most important.

Schopflin looks at pre-communist administrative and religious practices as the main cause of present-day political developments (1993, 5-6). State-society relations, the relative (in)dependence of the church, levels of state (de)centralization, these are most important factors determining subsequent political regime development. The post-communist world offers two types of legacies, concentrated in Eastern Europe and Russia, different from one another, and both different from the West European ideal type, where democracy is possible as a result of cumulative effect of centuries-old legacies $(1993,11)$. This difference between Russia as a clear example of state domination vis-à-vis society and church, and Eastern Europe where these forces are more in balance, apparently leaves some chances for democratization for the latter.

Schopflin however sees communist legacies as an additional burden on top of pre-communist legacies, making post-communist democratization a much more difficult task for Central and Eastern Europe, countries that have developed in between the two extreme political models. He follows the main points of Jowitt's argument in enumerating communist era legacies and discussing their negative impact on democratization. This explains why he shares Jowitt's pessimistic view 
on the possibility of fast post-communist democratization, although he does not rule it out completely in the more distant future (Schopflin 1993, 267 and 300).

Brzezinski (2002) looks at pre-communist legacies in order to find factors capable of eliminating negative affects of communist legacies. Like Jowitt (1992) and Schopflin (1993) Brzezinski looks at communist legacies as an amorphous body, without conceptualizing any internal sub-division. He argues that communist legacies' negative impact on democratization may be largely eliminated by a right dosage of pre-communist development.

Brzezinski looks at pre-communist history and culture as the main causes for post-communist development $(2002,196-197)$. He is mostly interested of traditions of state (de)centralization, of different state-church relations, and of the institutionalization of private economic entrepreneurship. Unlike Schopflin (1993) who puts East European legacies between Russia and Western Europe, Brzezinski divides Eastern Europe into sub-regions closely attached in terms of political behavior either to Russia as ideal type of state domination over society and church, or to Western Europe as representative of opposite trend. He predicts that there will be at least three groups of post-communist countries, developing into either authoritarian or democratic states or falling in between $(2002,194)$.

Hanson $(1995 ; 1997)$ 'unties the package' of communist legacies, making a difference between ideological, cultural, political and economic legacies. $\mathrm{He}$ accepts the argument that they all have negative impact on democratization. $\mathrm{He}$ however emphasizes the different speed with which they are overcome, that is, faster for ideological and political, and slower for economic and cultural.

The reason why Hanson 'unties the package' of communist legacies is that he tries to find an answer for post-communist diversity without abandoning the legacies approach as a basic paradigm and also without jumping to a pre-communist legacies explanation like Schopflin. Hanson argues that communist legacies represent a multilevel structure instead of an amorphous concept; different communist countries therefore are trapped into these legacies to a different degree. Democratization proceeds at different speeds; in Russia this process is slower than in Central and Eastern Europe (1997, 249-250). He explains this with the fact that 
communism in Russia is homegrown and that large social groups still feel attached to different communist legacies.

Hanson's model is dynamic in a sense that it does not preclude, once a certain democratization threshold is passed, a return to more authoritarian practices, e.g. October crisis in Russia in 1993 (1997, 243). Unlike Jowitt and Schopflin, and despite these reversals, Hanson is optimist as to the general direction of postcommunist democratization. For Hanson as well as for some other authors (e.g. Agopsowitcz and Landon 1995, 155) short-term democratic pessimism may coexist with mid-term democratic optimism.

\subsubsection{Legacy as possibility}

Not all scholars look at legacies as burdens impeding post-communist democratization. Some scholars, on the contrary, look at the past, communism included, as a source of inspiration containing seeds of possible democratic renewal. Within this stream we distinguish different approaches, focusing either on administrative practices (Kitschelt et al. 1999), on specific policies (Ekiert 2003), on changing role of communist parties from country to country (Grzymala-Busse 2003), or on different economic and social legacies left by decades of communism (Volgyes 1995; Curry 1995).

Kitschel et al. (1999) see legacies as inspiring both concern and hope regarding post-communist democratization. They argue that it is rather a unique combination of past political and administrative factors that mainly accounts for democratization. Some communist legacies are thus redeemed in accounting for post-communist regime diversity.

Two main legacies, going through both the pre- and communist eras, shape post-communist political development. One of them divides countries into two groups depending on whether they are administered by a formal bureaucracy or by a patrimonial ruler. The second legacy divides them into two groups depending on whether rulers repress opposition or co-opt its members $(1999,21-22)$. The crosscuttings between these groups create three possible political combinations: 
patrimonial/repressive, bureaucratic/cooptive and bureaucratic/repressive. These different combinations lead to variation in strength of the communist regime, patrimonial/repressive being the strongest; and to different types of post-communist transition: personal change or negotiated change or implosion; and also to different post-communist political regimes: democratic, authoritarian or intermediate (1999, 21-31).

Kitschelt et al.'s argument abandons the simplistic understanding that communist legacies are always a burden on democratization. These legacies can be assessed by the way they affect the post-communist political elite's rational choices as well as the choice of political institutions (Kitschelt et al. 1999, 14). Looking deeper into legacies will allow observers to see the seeds of different political paths behind the curtain of almost identical post-communist institutions.

Kitschelt et al.'s analysis is strong in finding causes for post-communist regime diversity remaining entirely within the legacies approach. It is also strong in naming the countries with the highest chances for democratization and consolidation, which are the Czech Republic, German Democratic Republic, and Poland. The weakest side of this analysis, however, is its inability to see the seeds of post-communist regime diversity within the largest group of seemingly identical cases falling into the crosscutting group of patrimonial/repressive states, e.g. Albania, Bulgaria, Romania, Turkmenistan and Uzbekistan (Kitschelt et al. 1999, 39). They are all expected to develop into authoritarian regimes, which is not true for some of them.

Grzymala-Busse $(2002 a ; 2002 b ; 2003 a ; 2006)$ focuses on the role of the Communist party. It is worth mentioning that communist parties are not easy subjects for conceptualization. They can play roles in different theoretical approaches: legacies, institutional choices and political leadership. Within the legacies approach Grzymala-Busse makes some interesting observations linking this party's internal structure and behavior, both before and after 1989, with the type of post-communist political regime.

Grzymala-Busse is a dissident voice when it comes to the role of communist successor parties in post-communist development. She argues that a proper 
structure of decision-making within this party, when higher echelons are given enough discretionary power in the latest periods of communist era, can be very helpful in overcoming inevitable communist rank-and-file opposition against democratization $(2003 a, 165)$. Higley et al. $(1996 ; 2002)$ qualify to a degree this benevolent role of the communist party top echelon by a factor that partly falls outside legacies' approach strictly speaking, namely the high level of political struggle during transition. The existence of a strong anti-communist opposition at the earlier stages of post-communist transition may or may not be part of the communist legacies.

A separate argument that Grzymala-Busse makes is that the process by which the communist party exits from power, disperses and regenerates, is vital for consolidating the post-communist political and party system (2006). Elements of this argument fall into another theoretical approach, institutional choices (see 2.2.1. Institutional choice as counterbalance against legacies). Here it is worth mentioning that some elements of it are also part of the legacy approach. Postcommunist party system as one of the main factors for democratization is almost entirely a communist byproduct; poor electoral performance by parties claiming any direct link with pre-communist political life is proof of this (Geddes 1995, 1997).

Volgyes (1995) argues that some fundamental elements within the communist system can also be counted as positive and necessary prerequisites for democratization. He divides communist legacies into two groups, either facilitating or impeding democratization. The first group includes industrialization, urbanization, centralized welfare, education, women rights, and to a degree egalitarianism. The second group includes etatisation, the psychological need for authority, and hyper centralization. All these factors are central, not secondary, for the successful functioning of communism; therefore they can be found in most communist countries. Political regime diversity and variations in the speed of democratization are therefore products of the impact of these socio-economic factors, e.g. Central and Eastern Europe have the best chances for democratization because they show higher level of first group facilitating factors and lower level of second group impeding factors. 
By looking mainly at socio-economic communist legacies the argument advanced by Curry (1995) looks similar to that of Volgyes. Unlike Volgyes, however, Curry is much more pessimistic about post-communist democratization in most countries. She does not see real opportunity for western type liberal democracy, and instead she predicts outcomes ranging from populist democracies through political fragmentations to open authoritarian regimes.

Ekiert (2003) follows the road of facilitating democracy legacies, naming factors that start producing effects in the late communist period. He mentions in this category economic liberalization, pragmatization of ruling elite, birth of a strong political opposition, as well as strong and ever growing ties with the West (2003, 115). Ekiert argues that the existence of such facilitating legacies, e.g. in Central and Eastern Europe, accounts for faster political regime democratization.

To summarize, legacies approach claims that past differences of the pre- and communist periods account for post-communist political regime diversity. There are however two opposing streams within this approach, seeing legacies either as a burden or an opportunity for post-communist democratization. Some see legacies as a uniform body affecting post-communist development in one or another direction. Others see legacies as a complex phenomenon where different past norms and institutions pull post-communist countries in different directions. Therefore scholars agreeing on legacy importance do not agree on how it does affect post-communist development. Some like Jowitt are pessimistic and do not predict democratization except in very rare occasions; others like Volgyes make optimistic predictions for democratization in many post-communist countries. In general, if any political democratization is to be predicted in post-communist countries, scholars agree that it will occur in Central Europe.

\subsection{Institutional choice approach}

This school of post-communist studies tends to explain political regime diversity by the unique for each country pattern of institutional development set up early on during post-communist transitional period. This school is partly an early reaction to the legacies-as-burden approach. This school balances undemocratic 
expectations by setting up institutions against legacies. It assumes that institutions are not neutral, and that some of them are friendlier for democratization. It focuses on the period immediately following the abolition of the Communist party's political monopoly, and therefore it is theoretically 'shallower' than legacies according to Kitschelt's classification (2003, 57-58). This school puts emphasis on factors such as the building of a sovereign state, on constitutional relations between different branches of power, and on electoral and party systems. Crafted initially as a reaction to the legacies' negative fatalism (Ackerman 1992), this school gradually develops into a body of studies comparing the relative pros and cons of different institutions (Shvetsova 2002).

\subsubsection{Institutional choice as counterbalance against legacy}

Institutional choice school shares assumption that communist legacies negatively correlate with democratization. It however presents the counterargument that new institutions can eliminate completely the effect of this negative correlation (Ackerman 1992). As the post-communist transition continues, the main focus of this school shifts from political revolution implying small window of opportunity to the ordinary political process. On the center stage, previously absent fundamental institutional elements emerge such as the need for a sovereign state (Linz and Stepan 1996) as well as small but important party system elements like communist successor parties (Grzymala-Busse 2006).

Ackerman (1992) looks at the events of 1989-1991 as a potential for new liberal revolution. There is, as during any revolution, a small window of opportunity, a 'constitutional moment' $(1992,3)$ when new institutions eliminating the legacy impact can be successfully set up. New institutions mean new constitutional arrangement between different branches of government, i.e. the separation of powers and a directly elected parliament. If these liberal institutions are set up during this short period of opportunity, they will then set in motion political processes independently from both legacies and from key political actors' preferences. According to Ackerman, the burden of legacies affects present political life through former and formal institutions $(1992,46)$. Once these institutions are 
replaced with new liberal ones, the negative impact of the legacy will quickly disappear.

Ackerman's model is optimistic regarding the chances for democratization. It is also egalitarian, Russia as well as any Central European country has its constitutional moment, when the burden of legacies may be eliminated $(1992,57)$. In a sense, this is negativist fatalist view of the legacies' approach taking complete U-turn, instead of all post-communist countries falling into the trap of their own past, they all can break with it and build democratic political systems.

Ackerman's argument has a powerful impact on the entire institutional choice school. Roeder (2001) in a similar vein, after shifting his theoretical approach from one more oriented toward political leadership to one more oriented toward institutional choice (for more on that see 2.3 Political leadership), explains democratization and the failure of authoritarian reversal with new liberal institutions like constitutional separation of powers set early on during the transition period. These institutions create a unique balance of power between key political players and therefore do not allow for the replacement of political bargaining with political monopoly $(2001,23)$.

Elster, Offer, and Preuss (1998) offer more optimistic view within institutional choice approach than Ackerman. This additional dose of optimism comes from the fact that the extremely crucial 'constitutional moment' disappears from the explanatory model. New liberal institutional arrangements still do matter for democratization, but not the timing of their initial setting up. Legacies have no substantial impact on post-communist political development, because no former institutions survive transition, which begins from 'tabula rasa' $(1998,18-19)$. It is rather a choice between institutions that ultimately facilitates or obstructs democracy. Institutions that facilitate democratization and democratic consolidation are liberal constitution, a parliamentary responsible executive, and political parties that are at the center of political action $(1998,109-111)$. Colton shares the argument that institutions do matter much more than legacies, and that orderly party systems and above all institutionalized executives who depend on party support are positively correlated with democratic consolidation (2004, 204-205). His 
quantitative research based on the Russian experience under presidents Yeltsin and Putin fairly well measures party strength and party roles within political system.

Grzymala-Busse (2006) looks within the post-communist party system at one important and structurally unavoidable element, the communist successor parties, and argues that the place they occupy and the weight they have within party systems correlates positively with improved political competition, which facilitates democratization. She predicts therefore that communist successor parties that fail in either early exit from power, or in early dispersion and regeneration are usually part of party systems where levels of competition are minimal, and therefore where democratization is weak or non-existent.

Linz and Stepan (1996) offer an additional prerequisite for democratic transition, the sovereign state itself, which is an element that post-communist democratization studies building upon traditions from South America and Southern Europe initially miss. Within the model Linz and Stepan present, a model that borrows independent variables from different schools, the building of a sovereign state is a paramount prerequisite for any political development, including democratization (1996, 16-19). Bunce (2004), building upon the Linz and Stepan's argument, presents a less complex and more cohesive theoretical model. It is ultimately strong state capacity that offers political elites some choice between different institutional arrangements and policies $(2004,229)$.

\subsubsection{Institutional choice threatening democratization}

Institutional choice scholars share the main premise concerning the causal impact institutions have on the political process, but they differ substantially on the direction of this process. Some argue that instead of facilitating democratization and its consolidation, some post-communist institutions may lead to democratic reversal. This stream within the institutional choice approach is largely consistent with Linz's argument about the perils of presidentialism (1990).

The 'perils of presidentialism' argument presents the executive office of the president, popularly elected and independent from political accountability to the national parliament, as a threat to democratization. Presidentialism facilitates a 
confrontational political style, leaves large sections of the population without adequate political representation, and uses political confrontation within parliament to increase executive power at the expense of legislature. The institution of a strong and popularly elected president therefore leads to democratic backslide.

Fish (2001) supports this argument in the context of post-communist transition. He sees in presidentialism the single most important factor accounting for democratization reversal. It does not matter whether a president has democratic worldviews or not. What does matter is that the president enjoys endorsement of popular confidence unmatched by other political players, that the domestic opposition is too weak to oppose his initiatives, and that the president enjoys the support of powerful external patron, e.g. Armenia, Kazakhstan, and Kyrgyzstan (2001, 73-75). To borrow from Ackerman's terminology, a strong president in the post-communist context may use the 'constitutional moment', the act of institutionalization of an independent executive, in order to shift the balance of power in his own favor.

Less categorical in his argument about the 'perils of presidentialism' is Frye (2002), who throughout the years gradually shifts his theoretical approach from political leadership to institutional choice (for more on that see 2.3.2. Powerseeking politicians). He agrees with Fish that presidentialism is negatively correlated to democratization, but puts a qualification that this correlation cannot be observed in all cases, e.g. Poland and Ukraine (2002, 100-102). Frye shares Fish's position that a strong office of president correlates positively with weak party systems and a fragmented parliament. Frye introduces an additional economic explanation for strong president; rent-seekers in countries with fragmented parliaments are looking for increased power for the president in order to preserve their economic advantages $(2002,82)$.

Ishiyama and Velten (1998) relegate the 'perils of presidentialism' argument to a secondary role in their explanation of post-communist regime development. The main cause is the electoral system for legislative elections; the proportional representation leads to democracy, while the single-member district system leads to 
authoritarianism $(1998,225)$. These electoral systems, they argue, ultimately decide how strong the party system will be in post-communist countries. Strong presidential institution therefore acts only as an intervening variable, producing democratic reversals in countries where the institutional basis for a strong party system is already undermined by non-proportional electoral system (1998, 228). Shvetsova largely agrees with Ishiyama and Velten's argument as to the central role party system plays in post-communist democratization $(2002,55)$. She discusses the role of other institutions in either facilitating or obstructing party system consolidation.

To summarize, the institutional choice approach claims that unique institutional development accounts for post-communist political regime diversity. There are two main streams within this approach, seeing institutional choice either as a facilitating or as an impeding factor for post-communist democratization. Some scholars see new liberal institutions like the separation of powers as always leading to democratization. Many see at least some institutions as threatening to democratization, e.g. presidential system and single-member district elections for parliament. Therefore even scholars who agree on the importance of institutional choice do not agree on how it affects post-communist development. Some are optimistic and do not predict democratic backsliding except in rare cases; others make more pessimistic predictions for democratization in many post-communist countries.

\subsection{Political leadership approach}

This approach pulls the center of research interest toward political actors, rather than legacies and new political institutions. It assumes that despite these legacies and institutional restraints key politicians still have plenty of freedom to change the picture according to their worldviews or preferences. Legacies and institutions however are not ignored. They may still act as potential intervening variables. The political leadership approach argues that the behavior of key political actors causes post-communist political regime diversity. Compared to legacies and institutional choices, the political leadership approach is much more an agency- 
oriented one within Kitschelt's classification (2003). Depending on the level of influence it allows from legacies and institutions, it may also be more or less agency-oriented within itself.

\subsubsection{Worldviews matter}

Within the political leadership approach, one stream argues that the worldviews of major political actors are the most important independent variable. It is the political ideology of those with the greatest power that ultimately leads to one or another political regime. For some scholars this explanation applies to all postcommunist cases (McFaul 2002); for others worldviews matter only when different political forces are more or less equal in strength (Brown 2002; Fish 2002). This stream within the political leadership approach allows for all possible political regime outcomes.

For McFaul $(2002 ; 2004)$ it is the worldviews of the strongest political faction that ultimately determines whether political regime is democratic, authoritarian, or intermediate, e.g. if the strongest faction has democratic worldviews the political outcome is democratic (2002, 213-214). For McFaul, therefore, countries like the Czech Republic and Hungary go democratic; countries like Belarus and Kazakhstan move toward authoritarianism; and countries like Albania and Moldova are intermediate regimes (2002, 227). Other factors like state capacity, western influence, or cultural legacies, may play but a secondary role in this model. If there is a balance of power between democrats and dictators the outcome will be an unstable regime. Nodia (2002) puts slightly less emphasis on worldviews; politicians may promote democracy not because they believe in it but because they find it necessary. In this case, key politicians recognize the compelling power of democratic ideals, and see the need to accept or at least to give the appearance of accepting these ideals and thus preserving a place in political decision-making in the long-term.

A key element in McFaul's model, second only to the elite's worldview, is the distribution of power between main political factions. What makes his approach consistent more with political leadership instead of with the legacy or institutional 
choice is that specific legacies and institutions do not cause this distribution of power. These more structural factors have intervening significance only through human actions $(2002,214)$. The real causality for McFaul flows from these agencies to political regime type.

Brown (2001; 2002) disagrees with McFaul that politicians' worldviews matter in all cases, regardless of power distribution. Taking Russia as an example, he argues that only when power is balanced between different political factions, only then worldviews matter more than other more structural factors. The political elite, during political stalemate, may choose for either democracy or dictatorship. Without such stalemate, more structural factors play predominant role in explaining regime evolution.

Fish (2002) abandons his previously held more institutional approach (2001) (for more on that see 2.2.2. Institutional choice threatening democratization) and like Brown argues that within an unconsolidated regime it is the choice of key political actors that causes regime diversity. Taking Russia as an example, he argues that different elements within Putin's policy can lead to different outcomes For example, the growing state monopoly over communications may lead to authoritarianism, but regularization of political competition may have positive implications for democracy (2002, 246-247). Both Brown's and Fish's models predictive force however is very limited. By leaving it up to key actors in Russia to decide on the nature of political regime, they allow for any possible outcome. Between the two models, Fish's is more complicated implying different logic behind many simultaneously taken decisions, some leading to more democracy and some to more authoritarianism.

\subsubsection{Power-seeking politicians}

Second stream within political leadership approach takes as central key politicians as rational choice actors seeking to maximize and to keep power. Some scholars look at political outcomes as closely following power-seeking politicians' original design (Roeder 1994); others see these outcomes as the result of incomplete contracting and therefore as not entirely following rational actors' expectations 
(Frye 1997). The power-seeking explanation within the political leadership approach always predicts a post-communist backslide to authoritarianism.

Roeder (1994) puts at the center of his analysis self-interested politicians, seeking to maximize their control over the political process. Democracy and authoritarianism are not functions of politicians' worldviews. Power-seeking politicians unrestricted by more structural factors cause authoritarianism. Democracy is possible only when these authoritarian plans fail to materialize. Different shades of authoritarianism are the only logical consequences of powerseeking politicians' actions.

Roeder's explanation is much more concerned with authoritarian than democratic regime outcomes. He argues that there are three types of authoritarianisms: autocracies, oligarchies, and exclusive republics. They differ according to the selectorate each regime establishes; the selectorate is a group posing a credible threat of removing policymakers from power $(1994,65)$. Clashes between competing strategies of power maximizing politicians produce these different authoritarianisms. Driven by rational choice dilemmas similar to security dilemmas in international relations $(1994,64)$, politicians choose among different regimes in order to keep as much power as possible. Roeder's model offers expectations that constitute authoritarian regimes as the norm, and democracies exceptions to this norm, failures in authoritarian plans. Notwithstanding legacies or new post-communist institutions, the real driving forces of political development are power-seeking politicians, trying to limit the ways they are held accountable. Within his model political actors' influence and prospects for democratization have negative correlation, e.g. in Belarus, Kazakhstan, and Ukraine.

Frye (1997) like Roeder (1994) puts power-seeking politicians at the center of political analysis. Frye claims that despite great uncertainty during transition actors understand their interests and design appropriate strategies for their accomplishment. Like Roeder, Frye looks at the different strategies power-seeking politicians design in order to keep and increase control over the political process. Frye starts from an incomplete contracting premise, where no decision can have entirely predictable outcomes, because nobody can predict every possible future 
contingency. Unlike Roeder, Frye sees authoritarianism not as a successfully accomplished plan pre-designed by power-seeking politicians, but rather as a possible outcome of incomplete contracting made by rational actors. Authoritarianism becomes especially feasible when the subject of this incomplete contracting is the establishment of a strong presidential institution. Such an institution usually implies large residual powers of decision-making outside initial contract. It therefore makes possible significant democratic backsliding and the destruction of liberal constitutional norms.

Frye (1997) and Frye (2002) have one important difference for the purpose of this study. Frye (1997) posits power-seeking politicians as a main cause of possible regime outcomes; therefore the institutions these politicians design act as intervening variables, able to facilitate or impede authoritarianism. Frye (2002), in contrast, takes elective presidential institution as the main independent variable causing authoritarianism (for more on that see 2.2.2. Institutional choice threatening democratization).

To summarize, the political leadership approach claims that major political actors cause post-communist political development. There are two main streams within this approach, looking for causes in politicians' worldviews or at them as rational actors in search for power maximizing. On the one hand, worldviews may cause opposing regime outcomes. On the other hand, politicians as rational actors, unrestricted by legacies and institutions, cause authoritarianism.

\subsection{External influence and support}

The external influence and support approach claims that there is causality and strong correlation between external factors and post-communist regime diversity. Unlike the other three groups of explanations: legacy, institutional choice and political leadership, different hypotheses within this approach can be situated anywhere on the structure-agency continuum, and also anywhere in terms of causal deepness. This approach arrives last chronologically; its main concepts emerge ten years and more after the start of post-communist transition. 


\subsubsection{Positive external influence toward democratization}

The external influence and support approach is divided into two main streams. One looks at western institutions, e.g. EU or NATO, as the main independent variables. They play a role in post-communist development either as active actors imposing new institutions, or as passive actors diffusing values and changing expectations among political elites in post-communist countries. This stream of thought establishes a positive correlation between external factors and democratization.

Vachudova (2005) presents a model in which the European Union (EU) exerts sometimes passive and sometimes active leverage in favor of democratization in Central and Eastern Europe. During the early stages of transition, the EU plays only a secondary role. With EU membership emerging as a real possibility, external factors begin playing an ever-increasing and even predominant role. From passive leverage, that is, acting mainly by influencing domestic political actors' expectations in the 1989-1994 period, the EU turns into a main driving force for democratization during the active leverage period after 1994.

For Vachudova EU influence is always positively correlated with postcommunist democratization. Its passive leverage changes domestic political elite rational calculations; its active leverage causes changes in political structures and increases political system competitiveness, thus shifting the balance of power against rent-seeking undemocratic elites $(2005,161)$. Vachudova's expectations are that the clearer promises are of EU membership, and the deeper the process of accession negotiations is, the more likely is that accession countries will have democratic regimes.

Pridham (2001; 2005) shares Vachudova's argument about the positive EU role in post-communist democratization. Unlike Vachudova, however, Pridham pays special attention to the much narrower time framework of accession negotiations (2005). This shorter period is important for post-communist democratization because it provides accession countries' elites with first-hand experience in the art of pluralist politics $(2005,115)$. Pridham's expectations positively linking Europeanisation and democratization are similar to those of 
Vachudova, despite his concerns about possible bureaucratization of relations with Brussels $(2005,226)$.

Barany (2004) looks at another external factor, namely at the North Atlantic Treaty Organization (NATO), as more supporting rather than causing postcommunist democratization. This organization does this by creating supportive international environment for securing national sovereignty for post-communist countries; the assumption here is that national sovereignty is the main prerequisite for any democratization. NATO also promotes democracy in certain specific areas such as civil-military relations and transparent military budgets $(2004,74-75)$. For Barany, correlation between prospects for NATO membership and democratization is positive.

Levitsky and Way (2005a; 2005b) do not restrict their analysis to one particular external factor causing or supporting democratization; they focus their attention on the West in general as a political, military and economic center without legitimate alternatives in the post Cold War world. Their model looks at democratization as caused by the cumulative impact of two different factors: western leverages, i.e. the level of pressure the West can exercise over postcommunist countries; and western linkages, i.e. the density of each post-communist country's ties with the United States, or EU, or Western-led multilateral institutions (2005a, 21). High external leverage and linkage lead in most cases to democratization, as is the case in Central Europe; high leverage and low linkage, e.g. Georgia and Moldova, lead to political instability but rarely to democratization; and low leverage and low linkage in most cases lead to authoritarian political outcomes, e.g. Russia and Belarus (2005a, 27-31). Everything else being equal, only higher linkage allows for external factors to play a predominant role in postcommunist development. Higher linkage with the West is always positively correlated with democratization.

\subsubsection{Mixed or negative external effect on democratization}

Another stream within the school of external factors is much less optimistic about the role they play in post-communist democratization. Some scholars have 
mixed expectations, separating and opposing short- from long-term EU impact. Others see danger for democracy or to its quality coming from the EU accession process, giving enormous power to executives at the expense of elected legislative bodies. Last but not least, by extending invitations to intermediate regimes to join the EU, this organization may unexpectedly give democratic legitimacy to these regimes and obstructs further democratization.

Kolarska-Bobinska (2003) argues that the EU integration process has mutually inconsistent short- and long-term effects on democratization. In the shortterm, Europeanisation leads to less democracy and to the rise of populist movements; in the long-term, however, it may lead to democratic reinforcement. EU integration in the short-term leads to neglect of the stabilization, strengthening and protection of many institutions, on which democratic order is ultimately based (2003, 91). Once EU membership is achieved, however, expectations are that the transfer of knowledge and skills, and the strengthening of public institutions will lead to democratic consolidation (2003, 97). Grzymala-Busse and Innes (2003b) share the view that EU integration has negative short-term correlation with the quality of democratization, without denying that the EU may positively affect postcommunist democratization in the long-term. They explain this short-term negative effect by the impact that Europeanisation has on political competition due to the fact that the EU imposes several non-negotiable requirements on accessing countries.

Kristi Raik (2004) argues that EU enlargement contributes to democratic erosion in post-communist countries without mentioning any time limitation. The logic of the inevitability of EU membership is not consistent with democratic principles. Accelerated speed of EU integration also contradicts a slower and more elaborated process of democratic bargaining. Effectiveness of EU accession negotiations is always negatively correlated with the level of democratic consolidation. Last but not least, an expert, elite-driven negotiation process creates a widening gap between domestic political elites and their electorates. The logic of Europeanisation promotes bureaucratic, executive-dominated policymaking and 
leaves little and ever shrinking room for democratic politics in applicant countries $(2004,591)$. Democratic quality erosion may turn into democratic regime erosion.

Bideleux (2001) argues that the EU is not a democratic but a liberal project, thus making baseless any expectations about possible democratization effects on new member countries. He shares some arguments advanced later by Raik, e.g. that the EU accession process gives enormous power to domestic executives at the expense of elected parliaments. Europeanisation and democratization are weakly correlated; when such correlation exists, Europeanisation is always negatively correlated to democratization. Therefore, by becoming more integrated into the EU, post-communist countries, without exception, find themselves increasingly regulated by rules, laws, decision, procedures and policies formulated in Brussels rather than domestically and democratically $(2001,27)$.

Gallagher $(2005 \mathrm{a} ; 2005 \mathrm{~b})$ argues in a similar vein, providing evidence from Romania that Europeanisation may sometimes correlate negatively with democratization. Unlike Raik and Bideleux, however, Gallagher's argument is that the EU helps in preserving old political patterns and behavior by giving democratic legitimacy to communist successor parties and leaders, which obstruct democratization. In this sense, the EU in Gallagher's model may preserve both democratic and undemocratic regimes.

To summarize, the external influence and support approach claims that external factors cause post-communist political regime development. There are two main streams within this approach, claiming that external influence can affect prospects for democratization either positively or negatively. Both streams look at the EU as a major foreign factor. Positive correlation with democratization occurs when the EU imposes new pro-democratic institutions or changes local political elite expectations. Negative correlation may occur when the EU limits the democratic process during the accession period or gives democratic legitimacy to undemocratic political forces. 


\subsection{Concluding remarks}

This chapter presented four different approaches to the problem of postcommunist political regime diversity: legacies, institutional choices, political leadership, and external influence and support. It reviewed their major arguments and expectations regarding post-communist development. It was the first logical step in researching post-communist regime diversity. In the following chapter these four approaches will be critically assessed. Four generic models will then be crafted, one for each approach. These models will turn the four major approaches into four theoretically testable hypotheses. 


\section{Generic models}

The purpose of this chapter is to present four generic models crafted out of the four approaches already presented in the previous chapter: legacy, institutional choice, political leadership, and external influence and support. A model here means simplified construct representing the main features of a theoretical approach and its hypothesis. Generic models combine mutually reinforcing independent variables from each approach. Purpose of this is to focus on four generic, comparable models, without which this project may become unmanageable.

There are three possible ways of crafting a generic model, which I will call selective, deterministic, and flexible. Each of them has strong and weak features. The selective approach requires using as many variables as possible, but only those that can be linked into a strong theoretical model. For example, medieval feudal norms of reciprocity cause the creation of formal bureaucracy through the mechanism of rule of law; but these feudal norms will neither determine communist rulers' political strategy nor these rulers' economic policy during communism. The selective approach therefore leads to the unacceptable elimination of many variables for the sake of theoretical rigidity. The deterministic approach assumes that the presence of all variables is necessary to produce one or another postcommunist political outcome. It assumes that all independent variables are mutually linked, and that only their cumulative action causes certain political outcomes. This approach does not leave behind any independent variable, but at the cost that it makes any clear-cut outcome almost impossible to achieve. The flexible approach, the one I use in this project, tries to eliminate weaknesses of these two approaches without compromising with the main goal of the project. It does not claim that all independent variables are correlated between each other. It does claim, however, that any of them may be correlated to a degree with final outcomes, which are postcommunist political regime and its diversity.

Once these four multivariable generic models are crafted, the task for the next chapter will be to test their relevance against post-communist case studies. We must be sure that even if this generic model correlates well with post-communist political development that this is not a spurious correlation. To do this, when we 
test a model against a post-communist case, we must control this correlation by introducing consecutively three other models presented in this chapter. For example, if correlation between model ' $\mathrm{A}$ ' and post-communist development in country ' $\mathrm{X}$ ' is positive, and by controlling for model ' $\mathrm{B}$ ' this correlation completely disappears then we may face a spurious correlation, then maybe ' $B$ ' would be a better cause for ' $\mathrm{X}$ '. If introducing other models do not change initial correlation between causes ' $A$ ' and development of country ' $X$ ' then the correlation is not spurious.

\subsection{Legacy generic model}

The legacy approach assumes that the unique historical experience of each country causes post-communist political development and possible political regime diversity. For the legacy generic model, therefore, all relevant independent variables should be located theoretically and chronologically before the end of the communist system.

There are several independent variables that fit well with this model. Some are easier to observe and measure than others. Our task here is to present a generic model combining mutually reinforcing elements that do not contradict each other, that are easily observable and measurable, and claim to cause post-communist political diversity.

Among the independent variables that Jowitt proposes (1992) good candidates for the generic model are lack of shared public identity of citizens, i.e. no symbolic equation between rulers and the ruled as members of one national community; communist party political monopoly, alienating the population from the political realm; development of semi-autarchic collective socio-economic institutions, all of which obstruct democratization. We will keep these variables for the legacy model. Regarding communist party political monopoly, an important new element comes from Grzymala-Busse (2003a), claiming that political monopoly of decision-making in the highest party echelons during latest communist period can benefit democratization. 
Another variable of Jowitt's, a culture of impersonal measured action, will be eliminated. He means by this that no communist country is able to create impersonal procedures replacing a corrupt set of patron-client relations $(1992,291)$. His statement does not provide evidence in support of such claim; moreover, Kitschelt et al. $(1999,21-22)$ provide evidence supporting the opposite claim, that at least some countries have no patron-client relations. In addition to this division between formal bureaucracies and patrimonial rulers, Kitschelt et al. offer a division between legacies of repression vs. cooptation. They claim that it is a combination of these cross-cuttings that leads to different post-communist outcomes.

Schopflin's (1993) independent variables are easy to observe and integrate into one generic model. They include an established through Middle Ages dichotomy between secular and religious legitimacy, obstructing later absolutism; fragmentation of power, which also goes back to the Middle Ages, ultimately facilitating rule of law; and creation of autonomous from the state commercial and urban spheres; all these variables ultimately facilitate democratization. Brzezinski's (2002) argument follows some of Schopflin's variables, e.g. secular-religious dichotomy and fragmentation of power. He indirectly elaborates on Schopflin's argument on an autonomous from the state commercial sphere by measuring it with the level of institutionalization of private entrepreneurship.

Hanson (1997) presents four independent variables affecting democratization. Some of them will be included into the generic model. Communist ideology is a commitment to the formal belief system of MarxismLeninism by both the elite and the broader population, and thus is easily traced down through interviews and public opinion polls (where available); Ekiert makes similar point (2003) when he puts forward ideological pragmatization of the elite as an independent variable facilitating democratization. Economic legacy, according to Hanson, is reduced to Stalinist planning and thus is mutually incompatible with market economy; Ekiert (2003) makes a similar point when he discusses economic liberalization during communism as facilitating 
democratization. Two other independent variables of Hanson's will be excluded from the generic model. Political legacy or the 'leading role' of the Communist Party is not just a communist era constitutional clause. The reason why we eliminate it is that Hanson's political legacy also includes the level of penetration of state bureaucracy outside elected elite with former communists, a phenomenon which is still not well studied. Another variable that should be eliminated is the cultural legacy of communism. The reason for this elimination is imprecise definition of 'culture' provided by Hanson, making it difficult to observe and measure.

Thus far we have more than a dozen remaining independent variables, each of them fitting well within the broad legacy approach. Some are nominal like existence of religious authority independent of state authority; others are ordinal like those offered by Volgyes (1995), e.g. the levels of industrialization, urbanization, and literacy, all, according to him, positively correlating with postcommunist democratization. Within the arguments presented by their authors these independent variables are not mutually exclusive; late communist economic liberalization is always positively correlated, and patrimonial rulers in the predemocratic era are always negatively correlated with expectations of postcommunist democratization.

Crafting our generic legacies model, we have the following expectations as to post-communist political regime development. We expect that countries experiencing all or most of the following patterns will develop into democracies: medieval dichotomy between secular and religious legitimacy; medieval and more recent fragmentation of political power; historical autonomy of commercial and urban spheres, with respective institutionalization of private property; formal bureaucratic rule and elite co-opting of opposition during communism; low level of communist party political monopoly over society; high autonomy of decisionmaking of high party echelons within the communist party at the end of communism; market liberalization during communism; low incidence of semiautarchic collective economic entities; high levels of elite ideological pragmatization; low level of ideological commitment toward Marxism-Leninism 
among both the population and elite during communism; high levels of industrialization, urbanization and literacy; and a high level of shared public identity between rulers and ruled during communism.

Conversely, we will expect that countries experiencing all or most of the following variables will develop into authoritarian regimes: a tradition of secular supremacy over religion; lack of history of political power fragmentation; no autonomy of commercial and urban spheres; patrimonial rule and elite the strategy of repressing opposition during communism; high levels of communist party political monopoly over society; low autonomy of decision-making of high party echelons within the communist party at the end of communism; sticking to Stalinist planning system until the end of communism; high levels of incidence of semiautarchic economic entities; low level of elite pragmatization; high levels of ideological commitment toward Marxism-Leninism among the population and/or political elite during communism; a low level of industrialization, urbanization and literacy; and low levels of shared public identity between rulers and ruled.

We expect that post-communist countries where the most important among these independent variables are more or less evenly distributed at the beginning of the transition may occupy intermediate positions between democratic and authoritarian post-communist regimes.

\subsection{Institutional choice generic model}

The institutional choice approach assumes that unique for each postcommunist country institutional development causes its political development and is ultimately accountable for political regime diversity. All independent variables of its generic model therefore are located theoretically and chronologically after the end of communist system.

It may seem unnecessary to repeat, but democracy, as any other stable political regime, requires a sovereign state. Unlike democratization studies focusing on Latin America and Southern Europe where the sovereign state is taken for granted, democratization studies on post-communist countries should begin with the state itself, given that most post-communist countries did not have a state within the 
international community of states at the start of transition. Linz and Stepan (1996) put the sovereign state as a main prerequisite for any possible democratization. It however does not automatically lead to democracy. Bunce (2004) builds upon this prerequisite by introducing another one, strong state capacity, allowing for possible democratization. It is not only some clear territorial distinction between different polities, but also the political elite's ability to choose between different institutional arrangements that ultimately make democracy possible.

Ackerman (1992) focuses on constitutional separation between different branches of government early in the during transition process. Such early separation accounts for regime diversity, because the 'window of opportunity' for overcoming the negative effects of legacies is relatively brief. Elster, Offe, and Preuss (1998) lift the time limitations needed for introducing new constitutional arrangements. Roeder (2001) concurs with them on this issue. For him, however, new constitutional arrangements act more as an insurance policy against possible authoritarian reversals than as a cause of democratization.

Elster, Offe, and Preuss also explain post-communist democratization with the central role that political parties play within political system $(1998,109-111)$, an argument with which Shvetsova concurs (2002). Colton (2004) adds a new element to the party system linking democratization to institutionalized executive dependent upon party support and responsible to parliament. Fish (2001) and Frye (2002) defend the same argument from a different perspective; they correlate democratic backsliding with institutionalization of a strong executive independent from party support and parliament, an argument consistent with the perils of presidentialism. This argument relates democratic backsliding with strong presidential power independent of elected parliament. Fish elaborates on this issue by introducing a variable reinforcing this peril, support for a strong executive from a powerful external patron.

Ishiyama and Velten (1998) do not reject the perils of presidentialism argument, but introduce a new, important, independent variable, electoral system for legislative election, that relegates the perils of presidentialism to a secondary position acting instead as a controlling variable. It is the single-member district 
electoral system for legislative elections that produces a weak party system and weak parliaments, giving political executives the opportunity to make authoritarianism possible. Grzymala-Busse (2006) looks within the post-communist party system at one structurally unavoidable element, communist successors parties, and more specifically at their behavior after beginning of transition. She argues that if they exit early from power, disperse, and regenerate, this will strengthen party systems, thus increasing political competition and making democracy more likely.

Thus far we have several independent variables, each of them fitting well within the institutional choice approach. They do not contradict each other, e.g. nobody claims that strong executive independent from parliament and parties increases the chances of democratization. Disagreements occur mainly regarding the relative weight of each variable, i.e. whether they are seen as main independent variables causing post-communist development, or acting more like intervening variables, increasing or diminishing the impact of other main independent variables.

Crafting our institutional choice generic model, we have the following expectations as to post-communist political development. We will expect that countries experiencing all or most of the following patterns will develop into democracies: the existence of a sovereign state over particular territory; strong state capacity to choose among different institutional arrangements; constitutional separation of different branches of government, such that the executive is dependent upon political party support; a proportional representation electoral system for legislative election leading to strong political parties system; and a communist successor party that exits early from power, disperses and regenerates.

Conversely, we will expect that countries experiencing all or most of the following variables will develop into authoritarian regimes: lack of an internationally recognized sovereign state over particular territory; weak state capacity to choose among different institutional arrangements; the executive is independent from parliament and from political party support and is supported by a powerful external patron; a single-member district electoral system for legislative election impeding the creation of strong parties system; and a communist successor party that does not exit early from power, does not disperse and does not regenerate. 
We will expect that post-communist countries where many of these independent variables are more or less evenly distributed at the beginning of the post-communist transition may occupy stable intermediate positions between democratic and authoritarian post-communist regimes.

\subsection{Political leadership generic model}

Political leadership approach assumes that it is the active and purposeful behavior of key political actors that causes political regime development unique for each country. The political leadership generic model therefore looks at political processes, instead of focusing on political legacies or political institutions. Legacies and institutions still may play a secondary role in political regime development. Despite their incentives or restraints, political actors still have plenty of freedom to change the situation according to their worldviews and rational calculations.

The political leadership model, unlike the previous two models, does not present a multitude of possible and alternative independent variables; it assumes that the main cause is located within very narrow circle of the political elite. Differences within this model therefore do not deal with the question 'what causes?' but rather with the question 'how they cause?' Political leadership model therefore will present different causal mechanisms linking political actors and postcommunist political regime diversity.

Two main streams within the policy choices approach look mainly at political actors' political ideology or at actors as power-seeking maximizers. McFaul $(2002 ; 2004)$ explains post-communist regime diversity by examining the ideology of the strongest political faction. This explanation is good for predicting either democratic or authoritarian trends, or intermediate political regimes. Roeder (1994), on the other hand, expects that power-seekers will always lead to postcommunist authoritarianism, making this approach weaker in terms of explaining democratization otherwise than as an authoritarian project failure.

Other authors reduce the explanatory power of the political leadership explanation to particular cases of post-communist development. Brown (2001; 2002) and Fish (2002) argue that political ideology causes political regime only if 
there is a balance of power between different political factions or within unconsolidated regimes. These multiple qualifications mean that for the purpose of our generic model, we must take McFaul and Roeder as basic representatives of each stream.

Instead of asking how to integrate political ideology and rational choice power seeking into one generic model, a question that may eliminate elements of both streams for the sake of their consistency, we will ask whether they really are incompatible. This is an approach where any possible answer but an absolute negative is acceptable; in the opposite case, all possible answers but an absolute affirmative would be considered unacceptable.

At first look, there is fundamental inconsistency between political ideology and power seeking. Ideology has a strong normative element regarding the allocation of power, regardless of whether this distribution benefits particular political actors. This normative element however creates own rational calculations as possible means leading to some particular goals. Within this broader understanding, the rational power-seeking actor is not incompatible with political ideology as long as this actor is using power for a particular goal consistent with ideology. Unlike Roeder's bleak expectations regarding the possibility of postcommunist democratization, democratic opposition leaders seek power mainly as means toward democratic goal; a goal unachievable without their participation in power, according to McFaul's expectations. Rational actor seeking power for the sake of absolute power is fairly consistent with authoritarian political ideology. To sum-up, rational calculation including power seeking is not theoretically incompatible with any particular political ideology. Sometimes it is ideology that causes particular rational calculations.

Crafting political leadership generic model we have the following expectations as to the post-communist regime development: we will expect that countries experiencing the following independent variables will develop into democracies: the strongest among post-communist political factions are democratically minded politicians, and there is consistency between the strongest political actors' worldviews and their rational calculations. Not so strong, but still 
democratic, are expectations for countries where strongest political factions are not democratically-minded, and there is no consistency between key political actors' political ideology and their rational calculations, these actors install democracy not because they see it as the right regime, but because they find it necessary (e.g. Nodia 2002).

Conversely, we will expect that countries showing the following independent variables will develop into authoritarian regimes: the strongest among post-communist political factions are authoritarian-minded politicians, and there is consistency between their worldviews and their rational calculations; or the strongest among post-communist factions are not authoritarian-minded, and there is no consistency between their political ideology and their rational calculations; in this situation key politicians install authoritarianism not because they believe in it, but because they think they benefit from it.

We will expect that post-communist countries where these variables are more or less evenly distributed at the beginning of transition will occupy stable intermediate positions between democratic and authoritarian regimes, e.g. democratic and authoritarian forces will be balanced, and the cost of changing this balance will be far greater than the possible benefits for each faction.

\subsection{External influence and support generic model}

The external influence and support approach tends to explain political regime diversity through variables geographically and/or institutionally located outside the post-communist region, or within this region but outside of countries under research, e.g. when one post-communist country influences political development in another post-communist country. This generic model, unlike the legacy, institutional choice and political leadership models, can therefore be situated anywhere on the structure-agency continuum, and also anywhere in terms of causal deepness.

This model addresses mainly the issue of EU impact on post-communist political development. With some notable exceptions where the EU does not play any conceptual role (Barany 2004), it is seen either as only the independent 
variable, or as the main variable acting in unison with other West-centered international organizations. The 'apple of discord' between different scholars comes mainly from the political direction post-communist countries take under active EU influence.

EU influence over post-communist countries increases with these countries expectations of becoming EU members. Most scholars agree (e.g. Vachudova 2005) that during the pre-accession period lasting for most of the 1990s the EU acts mainly through changing post-communist political elite expectations. Any move toward democratization is attributed to the elite's calculation that applying certain rules increases its chances of being considered democratic and therefore invited to join the EU. Democratization therefore is the price to be paid even by undemocratically minded politicians who want that their countries join EU.

Second mechanism that causes democratization is accession negotiations. Many scholars agree (Vachudova 2005; Pridham 2001; 2005; Levitsky and Way 2005a; 2005b) that the EU has powerful leverage to influence not only politicians' rational calculations, but also to require changes in political institutions and even in governments in exchange for inviting these countries to join.

Many scholars hold identical views positively correlating high expectations of EU membership and democratization during the pre-negotiation period. Scholars, however, sharply disagree on the effects of EU influence on democratization during the negotiation process itself. One group (Vachudova 2005; Pridham 2005; Levitsky and Way 2005a) sees it as a sign of even more active pro-democratic influence. Others (Kolarska-Bobinska 2003; Grzymala-Busse and Innes 2003; Kristi Raik 2004; and Gallagher 2005) hold opposing views. They argue that negotiating EU integration without any viable alternative is an undemocratic act; that the high speed of negotiations does not allow for any substantial democratic negotiations between post-communist elites and their constituencies; that EU accession process allows narrow post-communist elites to dictate the rules and direction to the rest of society; and that these elites therefore receive EU democratic credibility even if they have undemocratic political records. 
The points that most scholars disagree over are few but all of them require brief discussion. First, I do not accept that negotiating EU membership without any real alternative downgrades per se the quality of democracy because there is a large consensus in many post-communist countries on EU membership. Such consensus can be measured by looking at public opinion polls during the transition process. Second, if faster EU negotiations downgrade the quality of democracy, we may expect that some countries will clearly show democratization backslide during this process. Third, whether EU negotiations create and keep in office particular political elite can also be measured by electoral results before and after the EU accession process. If the EU negotiation process somehow erodes democracy or its quality, such backsliding can be observed and measured.

Apart from the EU, NATO also acts as a leading democratization factor. The argument Barany (2004) makes is that NATO membership stabilizes state sovereignty over particular territory, and also that it puts the military under civilian leadership, therefore acting as a prerequisite and cause for further democratic development.

Crafting external generic model we have the following expectations as to post-communist development. We will expect that countries experiencing the following patters will develop into democracies: countries with high expectations for EU/NATO membership in a reasonably short- to mid-term period; a population that supports EU/NATO integration; EU/NATO exercise strong leverage over postcommunist countries by requiring institutional and governmental changes in exchange for membership; a negotiation process that does not prevent normal democratic change of government and monopolization of political offices by unchecked elite; post-communist countries are not influenced mainly by strong authoritarian state.

Conversely, we will expect that countries experiencing the following patterns will develop into authoritarian regimes: countries with low expectations for EU/NATO membership in a reasonably short- to mid-term period; a population that does not support EU/NATO integration; EU/NATO does not exercise strong leverage over post-communist countries by imposing institutional and governmental 
changes; if EU/NATO allows post-communist countries to begin accession negotiations this process prevents normal democratic change of government by keeping in office undemocratic political elite; post-communist countries are influenced mainly by a strong authoritarian state.

We will expect that post-communist countries where these variables are more or less evenly distributed, e.g. bitterly divided political elite and public opinion over EU/NATO membership; or fairly equal influence coming from both EU/NATO and strong authoritarian states, will occupy stable intermediate positions between democratic and authoritarian post-communist regimes.

\subsection{Concluding remarks}

This chapter presented four multivariable generic models that turn four general theoretical approaches to the problem of post-communist political regime diversity into testable hypotheses. They look successively at historic legacies, postcommunist institutional choices, political leadership, and external influence and support. Each of these models is crafted to be theoretically sufficient in trying to explain post-communist political regime diversity, i.e. to explain why they become democratic, or authoritarian, or remain between these two extremes. These models are flexible, they include as many as possible of the independent variables found in the literature, which are internally not contradictory, and are mutually reinforcing. The next logical step will be naming representative cases of post-communist political development and testing these four models on each of them. 


\section{Post-communist cases. Testing models}

The purpose of this chapter is to present three case studies, Romania, Belarus, and Macedonia as representative of different political trajectories, namely democratic, authoritarian, and intermediate regimes (for more about the choice of these cases see 1.2. Methodology). It contains short narratives about each country, including information about its pre-communist, communist and post-communist period. Then each generic theory, legacy, institutional choice, political leadership, and external influence and support, is tested separately on each case to measure and discuss its relative explanatory power.

For Romania this chapter concludes that two models, institutional choice and international influence, give too optimistic a prediction regarding the first half of the 1990s, but are correct regarding the post-1996 period; the political leadership model for the early 1990s makes too pessimistic a prediction, but is correct for the post-1996 period; the legacy model is imprecise regarding the entire postcommunist period.

For Belarus this chapter concludes that three models, institutional choice, political leadership, and international influence, give predictions that are too pessimistic regarding the first half of the $1990 \mathrm{~s}$, but are very accurate in predicting political regime type after 1996 . The legacy model is again too imprecise for the entire post-communist period.

For Macedonia, two models, political leadership and international influence, are too pessimistic regarding the first half of the 1990s, and too optimistic regarding the post-1998 period. The institutional choice model gives two mutually exclusive but equally possible predictions, which are ultimately inaccurate. The legacy model is once again either too imprecise for the entire post-communist period or too pessimistic.

\subsection{Romania. General information}

Romania is currently the largest and most populous post-communist country in Eastern Europe west of the former USSR save Poland; its current population 
stands at 22.3 million. It is surrounded by other post-communist countries, lying to the east of Serbia and Hungary, the southwest of Ukraine and Moldova, and the north of Bulgaria. As of 2002, the largest ethnic group is Romanian (89.5\%), and the largest minority is Hungarian (6.6\%). The predominant religion is Eastern Orthodox Christianity (86.8\%), followed by different Protestant denominations (7.5\%) and Roman Catholic Christianity (4.7\%). The official language is Romanian $^{3}$.

Romania under this name exists since 1859 when two principalities, Wallachia and Moldavia, unite. The country gains independence and international recognition in 1878. Romania joins the Entente forces during World War I. After victory in the war, the country acquires new territories, mostly in Transylvania, partly populated with Hungarians. The country joins the Axis powers during most of World War II, participating in the invasion against the Soviet Union. Romania is defeated in 1944 by the Red Army and signs armistice joining the anti-Nazi military coalition during the final period of the war.

After World War II, Romania is part of the Soviet sphere of influence. In 1947, the Romanian king abdicates and people's republic is proclaimed. Up until the late 1980s Romania is ruled by a one-party communist regime. Between 1965 and 1989 Nicolae Ceausescu effectively rules the country. His power is supported by the secret police Securitate at the expense of the communist party leadership. At the end of 1989, in a matter of days Ceausescu is overthrown, put on trial, sentenced to death and executed (Chiriac 2001, 124).

After the fall of the communist regime until 1996, former communist party officials led by Ion Iliescu dominate the government. The first peaceful political transition occurs in 1996 when a large coalition of opposition parties, led by Emil Constantinescu, wins both presidential and parliamentary election. Successful and peaceful political transitions occur again in 2000 (Popescu 2003) and 2004 (Downs and Miller 2005). Romania is a Council of Europe member since 1993, a NATO member since 2004 and a European Union member since January 1, 2007.

\footnotetext{
${ }^{3}$ All statistical data regarding case studies' population, ethnicity, religion, and language is taken from CIA World Factbook 2006, available at https://www.cia.gov/cia/publications/factbook/index.html.
} 
Until 1996 Freedom House (Freedom House 2005) puts Romania into the category of undemocratic and intermediate countries; the country nevertheless moves toward democratization during this initial post-communist period. Since 1996, up until now the country is considered a 'free' state.

\subsection{Belarus. General information}

Belarus is a former Soviet republic in Europe; its current population stands at 10.2 million. Geographically it is located between other post-communist countries, east of Poland, southeast of Latvia and Lithuania, northwest of Ukraine, and west of Russia. As of 1999, the largest ethnic group is Belarusian (81.2\%), and the largest minority group is Russian (11.4\%). The predominant religion is Eastern Orthodox Christianity (80.0\%), followed by the Roman Catholic Church and different Protestant denominations. The official languages are Belarusian since 1991 as well as Russian since 1995.

Belarus exists under this name since 1918 when the Belarus National Republic is created for a brief period by the occupying German army. Between world wars, the territory of Belarus is divided between the Soviet Union (Byelorussian Soviet Socialist Republic) and Poland. At the onset of World War II Byelorussian Soviet Socialist Republic is given parts of eastern Poland. Between 1941 and 1944 the country is occupied by Nazi Germany. After the war the status quo is restored as a constituent part of the Soviet Union. It remains part of the union until the late 1980s.

In 1990, the Byelorussian Soviet Socialist Republic declares national sovereignty. It changes its name to the Republic of Belarus in 1991. The postcommunist and post-Soviet era is clearly divided into two dissimilar periods, before and after Alexander Lukashenko becomes a president (1994), bringing with him changes to the constitution (1996). During the first period, the country makes painful steps toward democratization and economic liberalization. During the second period, the country moves quickly toward the establishment of an authoritarian regime. 
At the international level, the Partnership and Cooperation Agreement between the European Union and Belarus, negotiated in 1995, never comes into force. With a brief suspension for some months during 1999, Belarus is a member of NATO's Partnership for Peace program, but direct military cooperation between Belarus and NATO is minimal.

Freedom House (Freedom House 2005) puts Belarus until 1996 into the category of intermediate regimes; the country later moves rapidly into the category of authoritarian regimes, where it remains up until the most recent report.

\subsection{Macedonia. General information}

Macedonia is a former Yugoslav republic, one of the smallest in territory and in population; its current population stands at 2.0 million. With the exception of Greece to the south, Macedonia is located between post-communist countries, to the east of Albania, the south of Serbia, and the southwest of Bulgaria. As of 2002 the largest ethnic group is Macedonian (64.2\%) and the largest minority group is Albanian (25.2\%). The predominant religion is Eastern Orthodox Christianity (64.7\%), followed by Islam (33.3\%). The official languages are Macedonian and Albanian. Turkish, Serbian, and Romany are official languages in municipalities where they represent at least $20 \%$ of the local population.

The territory of Macedonia is once part of the Roman, Byzantine, and Ottoman empires. The name Macedonia is coined after an ancient Greek kingdom. Until the early 1900s, the territory is part of the Ottoman Empire. During the Balkan wars of 1912-1913 the whole region is divided between Greece, Bulgaria, and Serbia. Today's Macedonia is taken by Serbia and, until the World War II, it is part of the South Serbia region of the Kingdom of Yugoslavia. During World War II Yugoslavia is occupied by the Axis powers and today's Macedonia is divided between Bulgaria and Italian-occupied Albania. After the war Macedonia is returned to Yugoslavia (People's Federal Republic of Yugoslavia) as a constituent republic (People's Republic of Macedonia). In 1963, both the federation and the republic change the adjectives 'people's' to 'socialist' in their respective names. 
Macedonia peacefully secedes from Yugoslavia in 1991 after a referendum, by keeping an option open for future federation with other former Yugoslav republics. Macedonia does not participate directly in any war fought on the territory of former Yugoslavia.

During the post-communist period, until the late 1990s, former communist party officials around Kiro Gligorov dominate executive power. The first political transition occurs in 1998 and 1999, when a coalition of opposition parties, led by Ljubco Georgievski, wins parliamentary and presidential election. Political transitions also occur in 2002 and 2006 parliamentary and 2004 presidential elections.

Macedonia becomes a Council of Europe member in 1995. It is a member of NATO's Euro-Atlantic Partnership Council and Partnership for Peace program. Macedonia aspires to become a NATO member and participates in NATO's Membership Action Plan. NATO-Macedonian relations are close. Macedonia applied to become a European Union member in 2004, and since late 2005 has been granted candidate status.

Freedom House (Freedom House 2005) puts Macedonia since the early 1990s the category of intermediate political regimes; the country shows stable scores throughout the entire post-communist period.

\subsection{Testing the legacy model}

The purpose of this section is testing the legacy model on all three cases consecutively, following the order Romania, Belarus, and Macedonia. It matches its variables to historical facts prior to the onset of post-communist transition. It concludes with a brief assessment of the legacy model's predictive power regarding political regime development.

Medieval dichotomy between secular and religious legitimacy. Romania lies on both sides of the major European religious divide, separating Eastern Orthodox Christianity and Roman Catholic Christianity since the $11^{\text {th }}$ century. Since same era, the Roman Catholic Church establishes legitimacy independent of political rulers. No such theological separation exists for the Orthodox Church, including during the 
communism (Linz and Stepan 1996, 451). The Romanian Orthodox population represents the vast majority. Romania shows some medieval dichotomy between secular and religious legitimacy, but it is vastly outnumbered by Orthodox tradition, and is mainly concentrated in the northwest periphery that never exercises political and religious authority over the country.

Belarus also lies on both sides of this religious division. The Orthodox population represents the vast majority, although there is however a significant Roman Catholic minority. For centuries Belarus territory is ruled within the political context of Polish-Lithuanian Commonwealth giving privileges to Roman Catholicism. Belarus shows some medieval dichotomy between secular and religious legitimacy, and also has a history of Roman Catholic domination. On the other hand, this legacy is counterbalanced by the contemporary domination of the Christian Orthodox population.

Macedonia lies to the east of this major European religious division. During medieval times there was no separation between secular and religious legitimacy for the Orthodox Church, or for the version of Islam imposed during Ottoman domination. The Orthodox and Muslim communities represent almost all of the population. Macedonia has no legacy of medieval dichotomy between secular and religious legitimacy. Among these three case studies, Belarus occupies a leading position because of its history as part of the Polish-Lithuanian commonwealth, Romania occupies an intermediate position, and Macedonia occupies the third position.

Medieval and more recent fragmentation of political power. Being for many centuries borderland between large multiethnic empires such as the Ottoman, Austrian, and Russian, two Romanian principalities Wallachia and Moldavia develop high levels of autonomy as well as a certain degree of internal political decentralization. This decentralization is gradually eliminated after they merge into the Romanian state in the second half of $19^{\text {th }} \mathrm{c}$. (Mot 2002, 230) Transylvania traditionally experiences political decentralization, based on a powerful local aristocracy; this decentralization is also gradually eliminated after it becomes part 
of Romania after World War I. In general Romania has a long history of political power fragmentation.

Up until the $18^{\text {th }} \mathrm{c}$. Belarusian lands are always part of loose and highly decentralized political entities, e.g. Kiev Russ and the Polish-Lithuanian Commonwealth (Pankovski and Markou 2005, 14). This tradition is reversed and eliminated when these lands are incorporated into the Russian Empire beginning in the $18^{\text {th }}$ c. (Chouchkevitch 2005). In general however Belarus has a long history of political fragmentation.

For most of its medieval history, Macedonia is part of multiethnic empires with substantial political and administrative centralization, such as Byzantine and Ottoman empires. Between the Balkan wars (1912-1913) and World War II it is directly ruled from Belgrade as part of the Kingdom of Yugoslavia. Macedonia has no medieval or more recent history of political power fragmentation. Among three case studies Romania together with Belarus shares the first/second position and Macedonia occupies the third position.

Historical autonomy of commercial and urban spheres. Autonomous commercial and urban centers both in Wallachia/Moldavia and in Transylvania exist as early as the late $12^{\text {th }} \mathrm{c}$. An important difference between these two historically distinctive parts of Romania is that in Transylvania this autonomy is promoted by Hungarian kings giving German colonists special privileges to build new towns, so-called 'German law towns', e.g. Kronstadt (Brasov), Klausenburg (Cluj-Napoca) and Hermannstadt (Sibiu) to name a few; on the other hand, in Walachia/Moldavia already established administrative centers are given limited commercial privileges. In general Romania has a history of commercial and urban autonomy, but it applies mostly to the Transylvanian region.

In Belarus this autonomy is established during the Polish-Lithuanian Commonwealth, providing large privileges under so-called 'German law towns' to Grodno in 1441, Minsk in 1499, Mogilev in 1577, and Vitebsk in 1597. Unlike Transylvania in Romania, German colonists did not initially build these cities in Belarus despite their similar legal status. Belarus too has history of commercial and urban autonomy. 
In Macedonia there is no history of autonomous commercial and urban centers. Multiethnic empires, that Macedonia is part of, have no tradition of giving such special privileges. Among the three cases Belarus occupies a leading position, Romania is second because its autonomy is mostly concentrated in Transylvania, and Macedonia occupies the third position.

Nature of rule and elite strategy during communism. These variables taken from Kitschelt et al. (1999) divide post-communist countries into two groups, those ruled during communism by a formal bureaucracy vs. patrimonial leader, and into two separate groups regarding the extent to which communist-era leadership uses cooptation or repression as a main strategy in dealing with opponents. This second variable is closely related to the level of communist party political monopoly (Jowitt, 1992). Romania up until the overthrow and execution of Ceausescu in late 1989 falls clearly within the group of communist countries ruled by a patrimonial leader using repression against any opposition (Gilberg 1990, 431). The level of communist party political monopoly until the end of the 1980 s remains high (Nelson 1990, 355).

Belarus as a part of the Soviet Union up until the end of communism is also ruled by patrimonial leaders using repression against opposition. This assessment however should be qualified given the process of personal-political paralysis due to communist leaders' illnesses since the early $1980 \mathrm{~s}$, as well as due to political liberalization under Mikhail Gorbachev's leadership in the late 1980s (Pankovski and Markou 2005, 16).

Macedonia up until the death of Tito in 1980 is ruled by a patrimonial leader using repression against opposition. The level of communist party political monopoly until the end of 1980 s remains high. During the 1980 s, however, the lack of a strong personality able to fill the vacuum left after Tito makes the nature of the rule more formal bureaucratic. Despite this there is no political liberalization in Macedonia as a part of Yugoslavia on the scale of Belarus as a part of the Soviet Union in the late 1980s. Among the three cases, Belarus occupies the leading position, followed by Macedonia, and Romania taking the third place. 
Autonomy of decision-making of high party echelons. In Romania up until the very end of the communist regime, political power is concentrated in the hands of the patrimonial leader (Linz and Stepan 1996, 348). His political and physical elimination in late 1989 does not change this power concentration. New government dominated by former party officials (Nelson 1990, 355; Siani-Davies 1996, 462) initially has large autonomy in decision-making, illustrated by its decision not only to set up rules for first democratic election, but also to take part in this election as one of many competing parties (Chiriac 2001, 124). In general, in Romania autonomy of decision-making is high.

In Belarus up until 1980 political power is highly concentrated into the hands of the patrimonial leader, Pyotr Masherau (Masherov) (Silitski 2005, 59). He dies in a suspicious car accident in 1980 after being in conflict with Soviet leader Leonid Brezhnev for quite some time (Marples 1999). Masherau's death leaves Belarus without strong political personality, and this republic during the $1980 \mathrm{~s}$ closely follows the political 'climate' of Moscow: 'deep freeze' during the first half and gradual political 'thawing' during the second half. Republican communist party leadership after 1980 has no significant autonomy of decision-making vis-à-vis Moscow and is completely powerless to block political decisions dismantling the Soviet Union and replacing it with the CIS (Way 2005, 247). To conclude, autonomy of decision-making in Belarus is very low.

In Yugoslavia, until 1980, political power is highly concentrated into the hands of the patrimonial leader, Josip Broz Tito. He dies after a long illness. His death unleashes two parallel processes of power decentralization, from federal to republican levels, and on each level, from personal to more collective decisionmaking bodies. As far as Macedonia is concerned its republican leadership receives additional power within the Yugoslav federation, but this power is more equally distributed among its own leaders, thus producing an inconclusive effect on the level of decision-making autonomy. The end of communist period therefore occurs without strong high party echelon able to take autonomous decision. Comparing cases, autonomy of decision-making is highest in Romania, followed distantly by 
Macedonia, and Belarus occupying the last place because of its clearer subordination to federal center.

Market liberalization during communism. Romania is a textbook example of Stalinist planning economy throughout its communist period (Nelson 1990, 359; Sabates-Wheeler 2001, 32). Its position begins to differ from other communist countries in the late 1980s when many of them introduce elements of market liberalization (Gallagher 1995, 66).

Belarus up until the mid-1980s is also a good example of the Stalinist planning economy. Some elements of market liberalization are introduced only in the late 1980 s, such as cooperative companies for consumer goods production, retail trade and some services.

Macedonia, as a part of Yugoslavia, stands apart from Romania and even from Belarus as a part of the Soviet Union in terms of market liberalization during communism. After brief post-Word War II period when Yugoslavia applies orthodox Stalinist planning; since the 1960s the ruling communist party introduces 'market socialism' concept, i.e. predominantly public ownership of the means of production and market mechanisms of allocating goods and services without strict planning. Among three case studies Macedonia occupies leading position, followed by Belarus, and Romania occupying the third position.

Level of elite ideological pragmatism and commitment toward MarxismLeninism. Romania begins its communist period with high ideological commitment to Soviet-style Marxism-Leninism. During this initial communist period, the level of ideological pragmatism is low. After Nicolae Ceausescu takes power, the county makes serious moves toward increasing the role of nationalism as a complementary ideology (Nelson 1995, 213). Romania distances itself from Soviet foreign policy (Linz and Stepan 1996, 347). In the 1980s, Romania embraces ideologically a more autarchic version of communism than most communist states. In general, the Romanian commitment to this modified Marxism-Leninism remains high.

Belarus is a good example of a lack of elite ideological pragmatism and of an unshakable commitment toward Marxism-Leninism. Even during the conflict between Masherau and Brezhnev, it remains largely at the personal, rather than 
political level. Belarusian local party elite always follows the official Soviet ideological interpretation of Marxism-Leninism. In general ideological commitment in Belarus is high and pragmatism is low.

In Macedonia communist party elite always follows ideological line set by the League of Yugoslav communists. As far as this general line includes some ideological pragmatism, e.g. nationalism and 'market socialism', Macedonian leadership is similarly pragmatic. In general, its ideological commitment to the Yugoslav interpretation of Marxism is high. Comparing the three cases, ideological pragmatism is strongest in Macedonia because of Yugoslav nationalism and the concept of 'market socialism', Romania is coming a distant second because of its nationalism, and Belarus occupies the third position.

Level of industrialization, urbanization and literacy. Before communism Romania is a predominantly agrarian country, with high level of illiteracy. By the end of the 1980 s agriculture engages only $28 \%$ of the total workforce and different industries engage $38 \%$. More than half of the population lives in urban areas by late 1980s. The level of literacy reaches $97 \%$.

In Belarus population is also predominantly agrarian before communism with high level of illiteracy. By the early 1990s agriculture engages only $20 \%$ of the total workforce, and different industries engage $42 \%$. Almost $70 \%$ of entire population lives in urban areas. The level of literacy reaches $99 \%$.

The Macedonian population before communism is predominantly agrarian with high level of illiteracy. By the early 1990s agriculture engages only $8 \%$ of the total workforce and different industries engage $40 \%$. More than a half of entire population lives in urban areas. The level of literacy reaches $96 \%$. Clearly, all three cases show remarkable progress during communism, and reach similar levels of development by its end. Given Volgyes's (1995) correlation between high industrialization, urbanization, and literacy, and democratic post-communist development, we should expect that all would show similar democratic patterns.

Level of shared public identity between rulers and ruled. Romania is for many generations a nation-state, and the politically relevant identity that unites rulers and the ruled during the communist 'nationalist' period is Romanian 
nationalism. Under Ceausescu, Romania eliminates the ideological domination of the Soviet Union, and therefore rulers are no longer considered to be primarily loyal to another state.

Belarus, during the communism, is part of the Soviet Union, and at the same time is home for one of its constituent nations, the Belarusian. A politically relevant identity uniting rulers and ruled does not exist because of the federal structural restraint; ordinary people in Belarus can perceive themselves both as Soviet and Belarusian citizens; and the rulers in Minsk and Moscow can mix federal and republican identities in different ratio (Chouchkevitch 2005; Pankovski and Markou 2005, 25).

Macedonia during the communist era is part of the Yugoslav federation, and at the same time is home for one of its constituent nations, the Macedonian. A politically relevant identity uniting rulers and ruled does not exist because federation imposes structural restraints; ordinary people can perceive themselves both as Yugoslavians and Macedonians, and the rulers in Skopje and Belgrade can mix in different ratio federal and ethnic identities. Macedonia has even less shared public identity than Belarus, another federative unit. Bulgaria and Serbia claim in the past that Macedonians are in fact Bulgarians or Serbs, while Greece traditionally claims rights over the name 'Macedonia'. These additional factors introduce even more confusion as to the public identity of the Macedonian people. In addition, an important part of the population, Albanians, does not even recognize itself within this identity (Barany 2005, 89-95). Comparatively speaking, Romania stands far ahead of the other two cases, followed by Belarus, and finally by Macedonia.

Within the legacy model, Romania presents a number of variables leading to post-communist democratization: a history of power fragmentation; high levels of decision-making autonomy of higher communist party echelons at the end of communist rule; a high level of communist industrialization, urbanization, and literacy; and high levels of shared public identity between rulers and ruled. On the other hand, Romania also shows variables leading to authoritarianism: the nature of communist rule is patrimonial and the main regime strategy during communism is repression; and lack of market liberalization during communism. Variables on 
which Romania performs intermediately are medieval secular-religious dichotomy; historical autonomy of commercial and urban spheres; and the level of ideological pragmatism during communism. Legacy in Romania does not represent one particular cluster, democratic, authoritarian, or intermediate; so it can push the country in either direction. According to Freedom House, however, Romania gradually develops after communism into a democratic regime. If legacy is a main cause for this development, then those variables where Romania confirms expectations of democratization become important for further elaboration.

Belarus presents the following variables leading to democratization: a history of medieval secular-religious dichotomy; a history of medieval political power fragmentation; a historical autonomy of urban and commercial spheres; and high level of communist industrialization, urbanization and literacy. On the other hand, Belarus presents variables leading to authoritarianism: the nature of communist rule is patrimonial and the main elite strategy during communism is repression except for a brief period in late 1980s; low autonomy of decision-making of high communist party echelon at the end of communism; no history of market liberalization during communism with the exception of the late 1980s; low ideological pragmatism during communism; and low level of shared public identity between rulers and ruled. Legacies in Belarus are concentrated at two opposing poles without intermediate nuance; they may promote either democratic or authoritarian political development. Belarus according to Freedom House develops after communism as intermediate regime moving in an authoritarian direction. If legacy is the main cause for this development, then variables leading to authoritarianism are therefore important for further elaboration.

Macedonia presents the following variables leading to democratization: market liberalization during communism; and a high level of industrialization, urbanization and literacy during communism. On the other hand, Macedonia presents far more variables leading to authoritarianism: it has no history of secularreligious dichotomy; no history of power fragmentation; no historical autonomy of the commercial and urban spheres; the nature of communist rule is patrimonial and the main regime strategy under communism is repression, with exception of years 
after the death of Tito; and low level of shared public identity between rulers and ruled. Variables where Macedonia performs intermediately are autonomy of decision-making of high party echelons at the end of communism; and the level of ideological pragmatism of the communist elite. Legacy in Macedonia therefore promotes predominantly authoritarian development. Macedonia, however, according to Freedom House, develops into an intermediate political regime, between democracy and authoritarianism. If legacy is a major cause of this development trajectory, then variables where Macedonia confirms intermediate regime expectations become important for further elaboration.

\subsection{Testing the institutional choice model}

The purpose of this section is to test the institutional choice model on all three cases consecutively. It matches its variables to evidence from the postcommunist transition period. It concludes with a brief assessment of the institutional choice model's power of prediction regarding political regime development.

Sovereign state. This variable looks at the existence of a sovereign state that is internationally recognized and not challenged by other political forces. Romania fits well with this notion of a sovereign state. Its borders remain unchanged since the end of the Word War II. Post-communist Romania is a legal successor of both communist and pre-communist Romania. It is internationally recognized as a state since 1878. There are no alternative forces claiming authority over parts of the territory despite ethnic diversity and existence of ethnic minority political parties (Stroschein 2001; Chirot 2005, 153-161).

Belarus exists as an independent and sovereign state since 1990-1991, when its parliament declares sovereignty (1990), and the Soviet Union ceases to exist (1991). As a Soviet republic, Belarus is internationally recognized with a seat in the United Nations after World War II (Chouchkevitch 2003). Real international recognition however occurs only after the collapse of Soviet Union. Sovereignty over its territory is not absolute given the lack of clear border demarcation with other post-Soviet republics like Lithuania, Latvia, and Ukraine. Moreover, groups 
of political refugees and former politicians living abroad for years claim to represent Belarusian people, casting doubts over current regime legitimacy (Pankovski and Markou 2005, 29).

Macedonia becomes an independent state peacefully in 1991. Greece's objection to the constitutional name 'Republic of Macedonia' delays international recognition until a compromise name is found (Perry 1996, 114; Ackermann 2000): Former Yugoslav Republic of Macedonia (FYR Macedonia or FYROM). It is only in 1995 that Greece lifts its trade embargo on Macedonia, thus allowing normalization of relations between Macedonia and EU, although differences over Macedonia's official name still remain. In addition, Bulgaria does not recognize the existence of the Macedonian language (Perry 2000, 134). This issue has important political consequences. Having a unique and internationally recognized language in the Balkan political context gives a particular ethnic group the right to claim to be a separate nation with the right to its own sovereign state. In 2001, an ethnic Albanian insurgency challenges governmental control over parts of the territory. Comparatively speaking, Romania occupies the top position in terms of state sovereignty, followed by Belarus, and then Macedonia.

State capacity. This variable determines whether there is capacity within the post-communist leadership to choose among different institutional arrangements, thus leaving behind the communist institutional legacy. In Romania, the political leadership does demonstrate sufficient state capacity. As an example, it takes less than two years to adopt the post-communist constitution based on the French model of strong presidential office (Mihut 1994, 412; Siani-Davies 1996, 464). This constitution undergoes major amendment in 2003 when the president and parliament's terms in office are separated, and the president's term in office is prolonged from 4 to 5 years.

Belarus declares sovereignty in 1990, but until 1994 its institutional arrangement remains within the framework of the Soviet constitutional legacy. Changing this legacy by establishing a strong office of president is not balanced by establishing other independent branches of government. This illustrates a weak capacity to choose among institutional arrangements. 
Macedonia quickly leaves behind communist era institutions, adopting a new constitution in late 1991. This constitution broadly follows the West European parliamentary model; the only element that stands outside this model is the office of the president, which is elected by popular vote. The political leadership again shows remarkable speed in revising the constitution after the ethnic Albanian insurgency of 2001, granting greater legal protection to minority rights (Hislope 2004). These facts show a high capacity to choose among different institutional arrangements. Comparatively speaking, Romania and Macedonia show far greater state capacity than Belarus.

Separation of powers. This variable looks at the constitutional separation of different branches of government, under which the institutionalized executive is dependent upon parliamentary and party support. Romania has constitutionally separated powers; the executive is split between the office of the president and a government that is politically responsible to both president and parliament (Popescu 2003, 325; Mihut 1994, 415). Two chambers of parliament are elected by proportional representation. The two parts of the executive, the president and government, represent different parties or coalitions throughout the entire postcommunist period. In Romania, the institutionalized executive is dependent upon parliamentary and party support.

In Belarus until 1994 there is no clear separation of powers; the country still uses the Soviet constitutional legacy, putting political executive under the supervision of constantly changing parliamentary majorities without clear party affiliation (Silitski 2005, 38-40). Since the presidential election of 1994 and the Lukashenko's rise to power, he does not rely on any parliamentary or party support.

Macedonia has a split executive, president and government. The president, since 1994, is elected by popular vote; the first presidential election is held by parliament in early 1991 . The first president, Kiro Gligorov 1991-1999, is formally independent from party support. Political parties, however, support all presidents that succeed Gligorov. The constitution of Macedonia assigns to the president few real powers. The government, on the other hand, always represents the party or coalition majority in parliament. Comparatively speaking, Romania and Macedonia 
have separation of powers and executives dependent on party support; Belarus has no such separation of powers and executive dependency on party support.

Electoral system and party system. This variable determines the electoral system for the legislative body, which in turn produces either a strong or weak party system; therefore the parliament is either dependent on or independent from party representation. Throughout the entire post-communist period, Romania applies proportional representation producing a parliament with strong democratic legitimacy and strong party affiliation among the electorate even before 1996 (Carothers 1996, 118).

In Belarus, before the rise of the authoritarian regime of Lukashenko, proportional representation is not used as the main electoral system (Shvetsova 1999). Between 1990 and 1995 the parliament is elected under a complicated and indirect Soviet system, initially not allowing non-communist political parties to compete. The election of 1995 is held under a mixed system that makes possible more than half of all future members of parliament to campaign as independent candidates (Marples 1999). Major political parties begin developing as late as 1993. Until 1996, when it becomes an authoritarian regime, Belarus is a country with an electoral system that does not facilitate the creation and development of political parties.

In the 1990s, Macedonia applies a mixture of single-member plurality and proportional representation (Shvetsova 1999; ICG Balkans Report 1998 and 1999); since 2002, parliament is elected by proportional representation producing even stronger party affiliation among the electorate. Comparatively speaking, Romania and Macedonia show similar electoral procedures promoting a strong party system; Belarus clearly falls far behind the other two cases.

Communist successor party behavior. This variable asks whether communist successor parties strengthen the party system by exiting early from power, dispersing and regenerating. In Romania, the communist successor party, the National Salvation Front, rules until late 1996 (Mungiu-Pippidi 2004, 386-388). It exits from power, temporarily, only after it loses both president and parliamentary elections. Even after 1996 it does not disperse (Gallagher 2005a, 17). In Romania, 
the communist successor party does not contribute to the strengthening of the party system.

In Belarus communist successor parties, one of which is temporarily banned in 1991 (Pankovski and Markou 2005, 18), control parliament until the rise of Lukashenko. These parties do not exit from power, disperse and regenerate until Lukashenko dissolves the parliament in 1996 (Chouchkevitch 2005). In Belarus, the communist successor party therefore does not contribute to the strengthening of the party system.

In Macedonia, the communist successor party, the Social Democratic Union, rules the country until 1998. It exits from power, temporarily, only after it loses both president and parliamentary elections (ICG Balkan Report 1998 and 1999). Even after 1998 this party does not disperse. In Macedonia communist successor party does not contribute to the strengthening of the party system. Comparatively speaking, in all three cases the communist successor parties do not contribute to the strengthening of the party system.

Within the institutional choice model, Romania presents the following variables leading to post-communist political democratization: the existence of a sovereign state; high state capacity; separation of power, with the political executive dependent on party support; and a proportional electoral system leading to a strong party system. On the other hand, the communist successor party's behavior in Romania has to lead to authoritarianism. Therefore, most institutional choices in Romania push the country towards democratization, which is confirmed by the Freedom House index after 1996. What makes this model not entirely convincing as the only cause for political development in the Romanian case is the slow speed with which it democratizes, given the pressure of so many favorable variables that come into effect immediately after the fall of communism.

Belarus does not exhibit any variables leading to democratization. The country does, however, show many variables leading to authoritarianism: weak state capacity; a political executive that is independent from party support; an electoral system that does not facilitate strong party system; and the communist successor party behavior. In only one variable, sovereign state, Belarus occupies an 
intermediate position. Therefore most institutional choices in Belarus push the country toward authoritarianism, which is confirmed by Freedom House index after 1996. With so many variables pushing the country toward authoritarianism from the very beginning of the post-communist transition, the only unsolved question within the institutional choice model regarding the Belarusian case is the existence of the early intermediate political regime.

Macedonia presents the following variables leading to democratization: high state capacity; separation of powers, with the executive dependent on party support; and a mixed moving to a proportional electoral system leading to a strong party system. On the other hand, Macedonia also exhibits other variables that lead to authoritarianism: weak state sovereignty; and the communist successor party behavior. Therefore institutional choices in Macedonia push the country both toward democratization and toward authoritarianism. According to Freedom House, Macedonia develops after the communism into an intermediate political regime. This model successfully predicts post-communist outcome in Macedonia if we are able to explain how exactly different institutional choice variables are able to cancel each other out.

\subsection{Testing the political leadership model}

The purpose of this section is to test the political leadership model on all three cases consecutively. It matches relevant variables to evidences from the postcommunist transition period. It concludes with brief assessment of this model power of prediction regarding political regime development.

Strongest post-communist political faction. In Romania, the strongest political faction emerging after the fall of Ceausescu's regime, the National Salvation Front, brings together politicians with strong anti-democratic political views (Gilberg 1990, 410; Carothers 1996, 120). This is evident given the numerous occasions in which the Romanian government uses unconstitutional support, e.g. appealing to coalmine workers for suppressing political opposition and for unleashing anti-Hungarian popular demonstrations (Nelson 1990, 357). This antidemocratic behavior continues for almost the entire post-communist period 
(Gallagher 2005a, 98). Even in opposition former communists use coalminers as tools for political struggle (Chiriac 2001, 126).

In Belarus, the strongest post-communist faction also has anti-democratic worldviews (Pankovski and Markou 2005, 17; Way 2005, 242). At no point during the post-communist period democratically minded politicians control executive power in Belarus, which is not completely institutionalized until the creation of a strong presidential office in 1994 . For the past decade, the country has been under Lukashenko's leadership, who does not even bother rigging elections and suppressing opposition.

In Macedonia, the strongest early post-communist political faction, and communist party successor, the Social Democratic Union, has anti-democratic worldviews. It eliminates existing ethnic minority rights (Perry 2000) and rigs elections, forcing part of the political opposition to boycott parliamentary election in 1994. The Social Democratic Union is either the dominant or the main opposition party in Macedonia throughout the entire post-communist period.

Consistency between worldviews and cost-benefit analysis. In Romania, the National Salvation Front and its political successor the Social Democratic Party is one of two main political parties throughout the entire post-communist period. Their political leadership remains largely unchanged. Their behavior, however, evolves gradually by eliminating unconstitutional political means for staying in or competing for power. By 1995, it already allows normal party competition resulting in an opposition electoral victory in 1996. Erosion of public support forces the party to look for larger political coalitions by including first technocrats then populists into government after 1993 (Ratesh 1993, 391; Chiriac 2001, 127). 1995 is a threshold year for Romanian politics. Romania becomes a EU associate member and its government must provide proof for its political democratization in order to be invited to join the Union. The Dayton peace treaty for Bosnia and Herzegovina makes NATO a key player in the Balkans and the West sends signals that populist regimes in the region will not be tolerated. As a result, the cost-benefit calculations of the Romanian leadership shift away from the ethnic populism and authoritarian 
regime option; one good illustration among others is the treaty with Hungary resolving the status of ethnic Hungarians in Romania (Chiriac 2001, 127).

In Belarus, the anti-democratic faction holds a majority in the parliament during the first half of the 1990s; the president Lukashenko who rules ever since has no strong democratic opponents to make concessions to; anti-democratic forces in Belarus are not under any democratic external pressure to provide freedoms in exchange for external support. Throughout the entire post-communist period, there is consistency between the strongest faction's anti-democratic worldviews and its cost-benefit calculation for staying in power.

In Macedonia, the Social Democratic Union's political behavior evolves gradually by eliminating the unconstitutional political means for staying in power and by making overtures to the Albanian minority. During the second half of the 1990 s, it already allows normal party competition, resulting in opposition electoral victories in 1998-1999. At that time, the crisis and subsequent war over Kosovo turns Macedonia into a host country for thousands of Albanian refugees. Macedonia counts on NATO to preserve its territory against Serbia, thus giving the West a strong leverage in favor of democratization. Political and interethnic openness in Macedonia is therefore a signal that it will not follow the Serbian model of ethnic cleansing and suppression of political opposition. As a result, the cost-benefit calculation of the Macedonian leadership shifts away from the authoritarian regime option.

Within the political leadership model, Romania presents two distinctive post-communist periods. Up to 1995 , the strongest political faction is antidemocratic, and there is consistency between its worldviews and its cost-benefit calculation, resulting in anti-democratic behavior. After 1995, this anti-democratic faction remains one of two main players in Romanian politics, but its cost-benefit calculation changes profoundly. Its worldview is no longer an obstacle to democratization. This model predicts that Romania has to have an authoritarian regime until 1995-1996, then it has to shift to a democratic regime as long as democratically minded politicians rule, then between 2000-2004 it has to remain democratic, but not so categorically, when communist successor party is again in 
government. According to Freedom House, Romania is an intermediate regime until 1996; it democratizes after 1996, and remains democratic without significant backslides. This explanation therefore is problematic for the first half of 1990s and more or less acceptable after 1996.

Belarus presents, with some important nuances, only one homogenous postcommunist period, producing expectations of an authoritarian regime. The strongest faction grouped within the parliament or around the president is anti-democratic, and there is consistency between its worldviews and its cost-benefit calculation. No strong democratic opposition ever threatens to take power during the entire postcommunist period. This model predicts that Belarus will have an authoritarian regime, although the level of authoritarianism may increase between the first and second half of the 1990s. According to Freedom House, however, Belarus is an intermediate regime until 1996, and not without opportunities to become democracy, and only in 1996 it becomes authoritarian and remains so. This model is problematic for the first half of the $1990 \mathrm{~s}$, but it has good predictive power for the later period.

Macedonia presents two distinctive post-communist periods. Up to 19981999, the strongest political faction is anti-democratic, and there is consistency between its worldviews and its cost-benefit calculation. After 1998-1999, this antidemocratic faction remains one of two main players in Macedonian politics. Under domestic and foreign pressure however its cost-benefit calculations change profoundly. Its worldview ceases to be an obstacle to democratization. This model predicts that Macedonia will have authoritarian regime until 1998-1999, then it will shift to democracy as long as democratically-minded politicians rule, then after 2002 it will remain democratic, but not so categorically, when the communist successor party is again in power. According to Freedom House, however, Macedonia is an intermediate regime throughout the entire post-communist period; it barely moves up or down on the political freedoms' scale. Instead of early authoritarianism and late democracy, we see a regime, which is neither a consolidated authoritarianism nor a consolidated democracy. 


\subsection{Testing the external influence model}

The purpose of this section is to test external influence model on all three cases consecutively. It matches its variables to evidence from the post-communist transition period. It concludes with a brief assessment of this model power of prediction regarding political regime development.

Expectations of EU/NATO membership. Since the early 1990s, Romania has high expectations for EU/NATO membership in the not so distant future (Gallagher 2005a, 158-164). The EU-Romania Trade and Cooperation Agreement of 1991 and the Europe Agreement of 1995, which open the door for formal submission of EU application, confirm these expectations. In 2000, Romania begins EU accession negotiations, and finally joins the EU on January 1, 2007. Regarding NATO, Romania receives early positive signals of increased cooperation by being invited into the Partnership for Peace program in 1994. In 2002 it is invited to join NATO, doing so in 2004.

In Belarus expectations for EU/NATO membership are low during the entire post-communist period. Even before 1996 these foreign policy options remain low priority for both politicians and the public opinion (Lahviniec 2005, 125). EU and NATO keep their relations with Belarus at s low level before 1996. At no point EU or NATO identify Belarus as a possible member within the reasonable future.

In Macedonia, expectations for EU/NATO membership during the 1990s are low. At that time, Macedonia is under trade embargo by Greece, a EU and NATO member, and Greece blocks any progress in EU-Macedonian and NATOMacedonian relations. Wars in the former Yugoslavia, although they do not directly affect Macedonia, are an additional deterrent factor for both the EU and NATO considering any enlargement that might include Macedonia. The situation begins to change after the fall of the Milosevic regime in late 2000, but it is partially reversed after sudden increase in multiethnic violence in 2001 . It is only after the Ohrid Agreement of 2001 ending military clashes between the Macedonian government and the Albanian minority, that EU gradually begin sending encouraging signals to Skopje. Regarding NATO, expectations for membership are even less clear than for EU membership. Macedonia is a member of NATO's Membership Action Plan but 
the country is not invited to join NATO during its Riga summit of November 2006. Comparatively speaking, Romania has the highest expectations for EU/NATO membership, and Belarus the lowest; Macedonia moves from low to relatively high expectations between the early 1990 s and early 2000 s.

Population supporting EU/NATO integration. The Romanian population overwhelmingly supports EU membership (Popescu 2003, 328; Chiriac 2001, 128). It is among the countries with the highest EU approval rating out of all postcommunist EU members and EU-candidates (Dostal and Markusse 2004, 234). This positive attitude does not change significantly over time. The Romanian population also supports NATO membership, although this support is less evenly spread over entire post-communist period, and in 1999, during the war in Kosovo, it experienced a drop (Gallagher 2005a, 213-225).

The Belarusian population does not support EU integration. According to different polls this option is supported by no more than a third of population (IISEPS 2006). It is much less popular than integration with Russia. The Belarusisan population does not support NATO integration either. In security matters, too, integration with Russia is preferable.

The Macedonian population recently shows strong support for both EU and NATO membership (USAID 2006). During the 1990s, however, this positive attitude is less categorical. Some parts of the population still see this integration as a possible threat to the national unity, as the membership is conditioned upon giving more rights to ethnic minorities. Comparatively speaking, the Romanian population shows the highest support for both EU and NATO integration, Belarus shows the lowest support, and Macedonia moves over time from moderate to strong support for both organizations.

EU/NATO leverage over post-communist countries. This variable accounts for post-communist countries vulnerability to external, in this case to EU/NATO, pressure. During the 1990s, EU engagement heavily constrains the government of President Ion Iliescu, making possible his defeat in the 1996 election (Levitsky and Way 2005, 28). Throughout the 1990s, all Romanian governments make EU/NATO 
membership a top priority in foreign policy thus contributing to high western leverage over the internal political process (Ratesh 1993, 394; Mot 2002, 375).

EU/NATO leverage over the Belarus is low despite some formalized contacts between Minsk and both international organizations. At no point after 1991 does membership in EU/NATO become a foreign policy priority.

Macedonian foreign policy during the 1990s evolves toward more openness vis-à-vis EU and NATO (Perry 2000, 133), and after the fall of the Milosevic regime in neighboring Serbia EU/NATO membership is declared a foreign policy priority. EU/NATO leverage increases very significantly afterwards (Agh 1999, 274). Comparatively speaking, Romania shows the highest EU/NATO leverage, Belarus shows the lowest, and Macedonia shows intermediate but rising leverage, recently catching parity with Romania on this issue.

EU/NATO negotiations and democratic change. Romania applies to join the EU in 1995. In 2000 they begin official accession negotiations. The country joins the EU on January 1, 2007. Regarding NATO, Romania first applies for membership in 1996; the invitation comes in 2002; and it joins the alliance in 2004. Since 1995/1996 when applications are first submitted, and since beginning of the NATO/EU accession process, political power changes hands in free and fair democratic elections (1996, 2000, and 2004). There are no indications that EU/NATO negotiations favor incumbents. On the contrary, the process of peaceful power transition begins in 1996, after the country applied for EU/NATO membership.

This variable does not apply to Belarus, which has not applied for either EU or NATO membership.

Macedonia applies to join the EU in 2004. In 2005, the EU gives Macedonia the status of a candidate country. Relations between Macedonia and the EU begin in 1996 when it becomes eligible for funding under the EC PHARE program. These relations intensify after the fall of Milosevic; in 2001, the EU and Macedonia sign a Stabilization and Association Agreement, which is a prerequisite to apply for EU membership. Macedonia seeks membership in NATO and is currently part of NATO's Membership Action Plan, a precondition for inviting a country to join the 
alliance. There are no accession negotiations between Macedonia and the EU/NATO, but the level of contacts is high. There are no indications so far that these contacts favor political incumbents during elections. It is however premature making conclusion whether future NATO/EU negotiations may influence political process.

Influence by strong authoritarian state. Since the early 1990s, the main external influence in Romanian politics comes from the West, either from democratically elected governments or from organizations of democratic governments (e.g. EU, NATO), or through international institutions in which democratic governments play dominant role (e.g. IMF, WB). At no point is the Romanian government influenced by a strong authoritarian state. At the critical moment of high anti-NATO public sentiments during the Kosovo campaign in 1999, the Romanian government follows the NATO political line.

For Belarus, the main external influence since early 1990s comes from Russia (Richard 2004, 50: Dostal and Markusse 2004, 234). For most of its transition, however, Russia is not an authoritarian country, it has intermediate regime throughout the 1990 s and early 2000 s. There is however political events in Russia before the 1994-1996, period when Belarus becomes an authoritarian regime, that may have influenced Belarus to become more authoritarian via demonstration effect, e.g. confrontation between the Russian president and parliament in late 1993 (Duhamel 2005, 91). This effect means that we cannot rule out completely the roles played by some undemocratic foreign actors.

Macedonia is influenced during the 1990s by Serbia, led by Milosevic, which becomes an authoritarian regime. This influence has several dimensions. The Macedonian economy is closely linked to Serbian. The Macedonian leadership, too, has close personal networks with leaders in Belgrade. Other Macedonian neighbors, Greece, Bulgaria, and Albania, are considered in Skopje to be threats, thus increasing the leverage of former federal center. This influence is one reason why Macedonia, even after the referendum on independence in 1991, keeps the door open for future federation with other former Yugoslav republics. This influence, however, disappears after the fall of Milosevic in late 2000. Comparatively 
speaking, Macedonia shows the highest influence by foreign authoritarian state until 2000, while Romania shows the lowest influence throughout the entire postcommunist period, and Belarus shows influence by foreign authoritarian patterns until it becomes an authoritarian regime.

Within the external influence model, Romania exhibits the following variables leading to post-communist democratization: high expectations of EU/NATO membership, a high level of popular support for EU/NATO integration, high EU/NATO leverage, and low influence by a strong authoritarian state. Romania shows no variables leading to either authoritarian or to intermediate regime development. External influence in Romania is concentrated into one particular cluster, pushing the country toward democracy. The question remaining unsolved is why a country so overdetermined to be democratic happens to have an intermediate regime for almost half of its post-communist period.

Belarus presents no variables leading to democratization, but presents variables leading to authoritarianism: low expectations for EU/NATO membership, low popular support for EU/NATO membership, and low EU/NATO leverage over Belarus. On one variable, influence by a strong authoritarian state, Belarus shows an intermediate result. Thus the variables for Belarus are almost entirely concentrated into one cluster, pushing the country toward authoritarianism. The question remaining unsolved is why a country so overdetermined to become autocracy has an intermediate political regime for several years.

Macedonia presents the following variables leading to democratization: high popular support for EU/NATO membership since the early 2000s, and a high level of EU/NATO leverage over Macedonia since early 2000s. On the other hand, Macedonia presents other variables leading to authoritarianism: a low level of EU/NATO leverage during $1990 \mathrm{~s}$, and strong influence by an authoritarian state during the 1990s. The variable where Macedonia shows an intermediate result is expectation for EU/NATO membership. External influence in the case of Macedonia divides its post-communist period into two very different sub-periods: during the 1990s, it pushes Macedonia toward authoritarian development; while since early 2000 s, it pushes the country toward democracy. Neither prediction fits 
well with Macedonia's stable intermediate status throughout the entire postcommunist period.

\subsection{Concluding remarks}

The four models make following expectations as regarding Romanian post-communist development: Legacy is not concentrated into one cluster; it can produce democratic, authoritarian, or intermediate political regime. Institutional choice is predominantly concentrated around the democratic pole, predicting early democratization. Political leadership predicts authoritarian regime until 1996, and democratic regime after that, with backsliding after 2000. The external influence model overwhelmingly predicts a democratic regime for the entire post-communist period. Thus two models, institutional choice and international influence, make more optimistic predictions for Romania before 1996. Political leadership, on the contrary, makes more pessimistic predictions for the same period. Legacy proves to be imprecise for the entire post-communist period. Three models, institutional choice, political leadership, and international influence, make the right predictions after 1996. All three, however, are problematic before 1996.

For Belarus, legacy is not concentrated into any one cluster; it can push the country in two opposite directions, toward either a democratic or authoritarian regime. Institutional choice is predominantly concentrated around the authoritarian option, predicting early autocracy and consolidation. Political leadership predicts an authoritarian regime throughout the entire post-communist period. The external influence model overwhelmingly predicts an authoritarian regime for the entire period. Thus three models, institutional choice, political leadership, and international influence, make more pessimistic predictions for Belarus for the first half of the 1990s, but provide accurate predictions after 1996. Legacy is too imprecise for the entire post-communist period.

For Macedonia, legacy is concentrated around authoritarian pole, although there are some variables pushing the country toward democratization or intermediate regime. Institutional choice is concentrated around two opposite poles, therefore making two mutually exclusive predictions, democracy or 
authoritarianism. Political leadership and external influence predict an authoritarian regime throughout most of the 1990s, and democratization thereafter. Thus two models, political leadership and international influence, make too pessimistic predictions for most of the 1990s, and too optimistic predictions afterward. The institutional choice model makes mutually exclusive and inaccurate predictions. Legacy is either imprecise for the entire post-communist period or far too pessimistic.

Across these three cases of post-communist political development, the legacy model at this stage of study appears to be the most incorrect answer to the regime diversity puzzle. It is too vague, making unspecific and mutually exclusive predictions. In the case of Romania, it predicts an equal probability of democratic, authoritarian, or intermediate development. For Belarus, it predicts either a democratic or authoritarian regime. For Macedonia, it wrongly predicts a tilt toward the authoritarian pole. To use this model further as a base for a new comprehensive model, it needs to be 'unpacked' in order to eliminate those variables that make it so imprecise, retaining only those that may correlate better with all three cases.

The institutional choice model makes better predictions, but it too is far from providing a convincing answer to the study's main question. For Romania, it predicts easy and fast democratization, which is incorrect for the first half of the 1990s. For Belarus, it predicts easy and rapid authoritarian consolidation, which is also inaccurate for the first half of the 1990s. For Macedonia, it predicts two opposing regime outcomes. To use this model as a base for further study it needs to be 'unpacked' and elements of it to be combined with elements of other models.

The political leadership model is far too pessimistic for all three cases. It predicts early authoritarianism, which is not correct in any country. However, it does provide an accurate prediction for subsequent political development in two countries, Romania and Belarus. For Macedonia, it predicts much more dynamic development from authoritarianism to democracy, rather than a stable intermediate position. To use this model as a base for further study, some elements of it may need to be combined with elements of other models. 
The external influence model is also somehow inaccurate. For Romania it predicts easy and fast democratization, which is not correct for the first half of the 1990s. For Belarus, it predicts easy and fast authoritarian consolidation, which is also not correct for the first half of the 1990s. For Macedonia, it predicts authoritarianism during the 1990s followed by democracy, which does not fit well with this country's stable intermediate status. To use this model as a base for further study some elements of it may need being combined with elements of other models. The next chapter will discuss a possible combination of elements of several models, and the construction of a new explanatory model. 


\section{Discussing findings. Building flexible cross- model explanation}

This chapter presents and discusses the level of accuracy of all independent variables that are part of the four major models of post-communist development: legacy, institutional choice, political leadership, and external influence. It begins by presenting a table (Table 2) including all independent variables and how they correlate with all three cases, with their entire post-communist period and/or some particular sub-periods, if there is substantial difference between them. It then discusses the study's findings by looking at possible cross-model explanations, beginning with the most theoretically rigid and ending with more flexible alternatives.

This chapter concludes that given existing independent variables in the literature it is impossible to craft a new rigid model of post-communist political development; rigid here means that independent variables apply to all cases for their entire post-communist period or to all their sub-periods. Alternative approaches to solving the problem, that is, introducing more flexible explanations, are, however, possible. They require making compromises and being less rigid either on some cases and/or on some sub-periods within post-communist development. I claim that for the period after the mid-1990s, the combination of two different institutional variables, presented in more details in Chapter 3: constitutional separation of powers and electoral system for legislature best explain trends toward democracy (Romania) and authoritarianism (Belarus); for the period before the mid-1990s, the main causal mechanisms still remain to be clarified. As for the intermediate political regime development, illustrated by Macedonia, the presence of shared identity between rulers and the ruled and the existence of a sovereign state provide the best complementary explanation.

The following table presents all independent variables and how they correlate with all three post-communist cases. These variables are identified in chapter 2 as part of a literature review on post-communist transition and discussed more extensively in chapter 4 as applicable to all three cases. In this table they all appear 'unpacked' from their respective general approaches, which may be one 
possible solution for eliminating their inconclusive prediction power. Variables that apply correctly to the entire post-communist period in a particular case are marked 'correct'; those applying to some sub-period only mention this exact period of positive correlation; those not applying to entire post-communist period or to all sub-periods are marked 'totally incorrect'; two boxes are left unmarked because one particular variable, EU/NATO negotiations' effect, does not apply to Belarus and it is too early to judge its effects on Macedonia. Thus, for example, marking as 'correct' the variable 'strong authoritarian state' for Romania means that lack of such influence, as described in Chapter 4, correlates well with the lack of authoritarian regime in this country throughout entire post-communist period.

\subsection{Impossibility of establishing rigid cross-models explanation}

The findings in table 2 show that there are some variables, parts of different 'unpacked' models that correctly match theoretical predictions across all three cases. This section tries to use these variables to produce a rigid cross-model explanation for post-communist regime diversity. This rigid explanation must satisfy two conditions. First, it must show positive correlation for some variables across models for all three cases. Without this it will not satisfy the criterion of generalizability. Second, it must also prove links of causality between these variables and political outcomes. Without this precondition correlation may turn out to be spurious. A more detailed look at these variables shows however that they cannot offer a new rigid cross-model explanation for post-communist regime diversity. Despite their correlations in certain periods of post-communist development, most of these variables contradict their proper logic. This section will prove this point. In searching for a post-communist regime diversity explanation we therefore need to look for more flexible theoretical alternatives.

There are six variables that positively correlate to all three cases of postcommunist development. These variables are party high echelon autonomy during last period of communism, elite pragmatism during communism, and shared identity between rulers and ruled (legacies); sovereign state (institutional choice); 
and EU/NATO leverage and strong influence by a foreign authoritarian state (external influence and support). Each of three variables representing legacies predicts political development correctly after 1996 for all three cases but only in one case do any of them positively correlate before 1996 . Sovereign state correlates positively to all three cases only after 1996. EU/NATO leverage does not correlate positively to even one particular sub-period across all cases. Strong authoritarian state influence, as findings show, correlates positively only during most of the 1990s.

The logic of having party high echelon autonomy during the last period of communism as beneficial for democratization is precisely because this autonomy brings immediate positive results early in the transition, not many years later. Similar logic, although not so categorical, finds expression with other variables inside the legacy approach, elite pragmatism and shared public identity between rulers and ruled. At earlier stages of transition it is legacy, political leadership, and external influence that can somehow determine political development; institutional choice is a factor that still needs to be designed and executed and then it can only produce particular results after a certain time lag. What this table illustrates however is that the political leadership factor is initially correct only for Romania and only as far as consistency between worldviews and rational choice is observed. Another factor that initially correlates well with all three cases is influence by a strong foreign authoritarian state within the context of external influence; but let us not forget that in case of Romania this influence has zero value, as this country is not influenced by such a state. This makes legacy the only logical option for starting explaining early post-communist transition. Within rigid model applicable to all three cases however some elements of legacy correlate positively only for mid-term transition objectives, not to early transition.

Within institutional choice, looking at a sovereign state as the basic variable for unlocking the puzzle of early transitional development is also unfruitful. Being a sovereign state per se does not make any particular country democratic or authoritarian, although it is a vital precondition for stabilization of either regime option. Not surprisingly, it is good for Macedonia as a country that remains in 
Table 2. Independent variables / post-communist countries correlation

\begin{tabular}{|c|c|c|c|c|}
\hline & $\begin{array}{l}\text { Countries / } \\
\text { variables }\end{array}$ & Romania & Belarus & Macedonia \\
\hline \multirow[t]{9}{*}{ Legacy } & $\begin{array}{l}\text { Secular/religious } \\
\text { dichotomy }\end{array}$ & $\begin{array}{l}\text { Correct until 1996; } \\
\text { incorrect afterward }\end{array}$ & Totally incorrect & Totally incorrect \\
\hline & $\begin{array}{l}\text { Power } \\
\text { fragmentation }\end{array}$ & $\begin{array}{l}\text { Incorrect until } \\
1996 ; \text { correct } \\
\text { afterward }\end{array}$ & Totally incorrect & Totally incorrect \\
\hline & $\begin{array}{l}\text { Commercial and } \\
\text { urban autonomy }\end{array}$ & $\begin{array}{l}\text { Correct until 1996; } \\
\text { incorrect afterward }\end{array}$ & Totally incorrect & Totally incorrect \\
\hline & Elite strategy & Totally incorrect & $\begin{array}{l}\text { Correct until 1996; } \\
\text { incorrect afterward }\end{array}$ & Correct \\
\hline & $\begin{array}{l}\text { High party } \\
\text { autonomy }\end{array}$ & $\begin{array}{l}\text { Incorrect until } \\
\text { 1996; correct } \\
\text { afterward }\end{array}$ & $\begin{array}{l}\text { Incorrect until } \\
\text { 1996; correct } \\
\text { afterward }\end{array}$ & Correct \\
\hline & $\begin{array}{l}\text { Market } \\
\text { liberalization }\end{array}$ & Totally incorrect & $\begin{array}{l}\text { Correct until 1996; } \\
\text { incorrect afterward }\end{array}$ & Totally incorrect \\
\hline & $\begin{array}{l}\text { Elite } \\
\text { pragmatism }\end{array}$ & Correct & $\begin{array}{l}\text { Incorrect until } \\
\text { 1996; correct } \\
\text { afterward } \\
\end{array}$ & $\begin{array}{l}\text { Incorrect until 1998; } \\
\text { correct afterward }\end{array}$ \\
\hline & $\begin{array}{l}\text { Industrialization, } \\
\text { urbanization, } \\
\text { literacy }\end{array}$ & $\begin{array}{l}\text { Incorrect until } \\
1996 ; \text { correct } \\
\text { afterward }\end{array}$ & Totally incorrect & Totally incorrect \\
\hline & Shared identity & $\begin{array}{l}\text { Incorrect until } \\
\text { 1996; correct } \\
\text { afterward } \\
\end{array}$ & $\begin{array}{l}\text { Incorrect until } \\
\text { 1996; correct } \\
\text { afterward }\end{array}$ & Correct \\
\hline \multirow[t]{5}{*}{$\begin{array}{l}\text { Institut. } \\
\text { Choice }\end{array}$} & Sovereign state & $\begin{array}{l}\text { Incorrect until } \\
1996 \text {; correct } \\
\text { afterward } \\
\end{array}$ & Correct & Correct \\
\hline & State capacity & $\begin{array}{l}\text { Incorrect until } \\
\text { 1996; correct } \\
\text { afterward }\end{array}$ & $\begin{array}{l}\text { Incorrect until } \\
\text { 1996; correct } \\
\text { afterward }\end{array}$ & Totally incorrect \\
\hline & $\begin{array}{l}\text { Separation } \\
\text { of power }\end{array}$ & $\begin{array}{l}\text { Incorrect until } \\
\text { 1996; correct } \\
\text { afterward }\end{array}$ & $\begin{array}{l}\text { Incorrect until } \\
1996 ; \text { correct } \\
\text { afterward }\end{array}$ & Totally incorrect \\
\hline & $\begin{array}{l}\text { Electoral system/ } \\
\text { party system }\end{array}$ & $\begin{array}{l}\text { Incorrect until } \\
\text { 1996; correct } \\
\text { afterward }\end{array}$ & $\begin{array}{l}\text { Incorrect until } \\
\text { 1996; correct } \\
\text { afterward }\end{array}$ & Totally incorrect \\
\hline & $\begin{array}{l}\text { Communist } \\
\text { successor party }\end{array}$ & $\begin{array}{l}\text { Correct until 1996; } \\
\text { incorrect afterward }\end{array}$ & $\begin{array}{l}\text { Incorrect until } \\
\text { 1996; correct } \\
\text { afterward }\end{array}$ & Correct \\
\hline \multirow[t]{2}{*}{$\begin{array}{l}\text { Politic. } \\
\text { Leader- } \\
\text { ship }\end{array}$} & $\begin{array}{l}\text { Strongest } \\
\text { political } \\
\text { faction } \\
\end{array}$ & $\begin{array}{l}\text { Incorrect until } \\
\text { 1996; correct } \\
\text { afterward }\end{array}$ & $\begin{array}{l}\text { Incorrect until } \\
\text { 1996; correct } \\
\text { afterward }\end{array}$ & Totally incorrect \\
\hline & $\begin{array}{l}\text { Worldviews } \\
\text { consistency }\end{array}$ & Correct & $\begin{array}{l}\text { Incorrect until } \\
\text { 1996; correct } \\
\text { afterward }\end{array}$ & Totally incorrect \\
\hline \multirow[t]{5}{*}{$\begin{array}{l}\text { External } \\
\text { influence }\end{array}$} & $\begin{array}{l}\text { EU/NATO } \\
\text { expectation }\end{array}$ & $\begin{array}{l}\text { Incorrect until } \\
\text { 1996; correct } \\
\text { afterward }\end{array}$ & $\begin{array}{l}\text { Incorrect until } \\
\text { 1996; correct } \\
\text { afterward }\end{array}$ & $\begin{array}{l}\text { Correct until 2000; } \\
\text { incorrect afterward }\end{array}$ \\
\hline & $\begin{array}{l}\text { EU/NATO } \\
\text { support }\end{array}$ & $\begin{array}{l}\text { Incorrect until } \\
\text { 1996; correct } \\
\text { afterward }\end{array}$ & $\begin{array}{l}\text { Incorrect until } \\
\text { 1996; correct } \\
\text { afterward }\end{array}$ & $\begin{array}{l}\text { Correct until 2000; } \\
\text { incorrect afterward }\end{array}$ \\
\hline & $\begin{array}{l}\text { EU/NATO } \\
\text { leverage }\end{array}$ & $\begin{array}{l}\text { Incorrect until } \\
\text { 1996; correct } \\
\text { afterward } \\
\end{array}$ & $\begin{array}{l}\text { Incorrect until } \\
\text { 1996; correct } \\
\text { afterward }\end{array}$ & $\begin{array}{l}\text { Correct until 2000; } \\
\text { incorrect afterward }\end{array}$ \\
\hline & $\begin{array}{l}\text { EU/NATO } \\
\text { negotiations' effect }\end{array}$ & Totally incorrect & Not applicable & Too early to say \\
\hline & $\begin{array}{l}\text { Strong } \\
\text { authoritarian state }\end{array}$ & Correct & Correct & $\begin{array}{l}\text { Correct until 2000; } \\
\text { incorrect afterward }\end{array}$ \\
\hline
\end{tabular}


between two extremes; it is good to a degree for Belarus because it shows its gradual state consolidation, but definitely not for Romania early on in the transition. Most other variables within institutional choice are also unable to correctly predict initial transitional development. The only exception is communist successor party behavior, but here all three cases show very similar patters. This means therefore that this variable can explain possible political regime uniformity across cases, but not diversity.

Political leadership also does not provide an answer for early transition development. In addition it turns to be completely inaccurate in the case of Macedonia for its entire post-communist development. Within the context of external influence, apart from foreign authoritarian state influence, EU/NATO leverage is an interesting variable that at first sight may provide useful understanding of post-communist regime development. Unfortunately, it too has no correlation with early transition in two cases, Romania and Belarus. Only for Macedonia does it have useful early correlation, despite the fact that leverage is rather weak during this period.

To sum-up, despite some cross-model variables that positively correlate with post-communist regime development in all three cases, more detailed analysis shows that this correlation is not sufficient to construct a rigid model explaining post-communist regime diversity. Most positive correlations are not so strong for the entire post-communist period. Where such correlations exist, they often contradict the logic of some variables, e.g. some legacy variables do not act during early transition, but act only a after substantial period of time without any good explanation for this time lag.

The possible reason for being not able to build a rigid model of political regime diversity may be product of the project design itself. We expect from the very beginning three possible political options: democracy, authoritarianism, and intermediate regime, following Freedom House's classification. Is it possible that most of the literature we take our variables from is much more interested with explaining opposite regime types, e.g. democracy or authoritarianism, without 
paying enough attention to intermediate regimes? If this critique is true, then we will not observe enough positive correlations in Table 2 of any or most variables in the Macedonian case, as it is an intermediate regime. In fact, however, we see that more than half of all variables may allow for possible correlation with different aspects or periods of Macedonian regime development, meaning that at least half of all variables may allow for intermediate regime development. This critique nevertheless should not be completely ignored. The other two cases, Romania and Belarus, may allow for correlations with even more variables than Macedonia, meaning at least some variables may allow for only two possible regime options, democracy or authoritarianism, ignoring intermediate regime as a third possible option. Being unable to craft a rigid model of political development, we must then look at the second best option, i.e. building a more flexible model.

\subsection{Tentative attempts of establishing flexible cross- model explanation}

One way of making an explanatory model less rigid is by negotiating a compromise on one of the cases. This does not mean, however, that one postcommunist country will be completely eliminated from explanation in order to satisfy the hypothesis' requirements. Each country within the sample represents a particular transition pattern. Such elimination therefore will greatly reduce the effect of generalizability of any theoretical explanation. An alternative way to proceed is by taking a two-stage approach. At the first stage, two opposing cases, Romania and Belarus, will test all 'unpacked' independent variables. Once these variables representing a rigid theoretical model are identified, Macedonia as a intermediate case will be introduced. Variables that positively correlate to this intermediate case will not by default match the other two cases; otherwise we will have a rigid across countries explanation. Stage two therefore will answer questions such as, what makes possible intermediate political development, or what prevents democratic or authoritarian trends from fully developing.

At stage one, reducing the number of cases from three to two, Romania and Belarus, increases the number of positively correlated variables from six to thirteen. 
Three new variables come from institutional choice: state capacity, constitutional separation of power, and electoral system for legislative body; two new variables represent political leadership; and two new variables represent external influence: EU/NATO expectations for membership, and EU/NATO public support. At stage two, Macedonia will be introduced shortly with five variables positively correlating during its entire post-communist period. Three of them come from legacy model: elite strategy during communism, party high echelon autonomy, and level of shared public identity between rulers and ruled; and two come from institutional choice: sovereign state and communist party successor behavior.

There are two problems appearing on at stage one. With exception of only one variable, namely influence by a strong foreign authoritarian state, there are no other variables that correctly predict political development for both Romania and Belarus for the entire post-communist period. The problem with this remaining variable is that in the case of Romania, it has zero value, meaning it is the lack of influence by foreign authoritarian state that allows for particular political development, meaning other factors whose value is different from zero must play decisive role in this country's development. Another problem on stage one is that all positively correlating variables in fact act as predicted only after a time lag of several years. They may explain post-communist development well only when Romania and Belarus turn into democracy and authoritarianism respectively. Some correlate well with early transition in only one of these countries; most do not correlate well with early transition at all.

One way of solving these problems is to limit the number of variables applicable to both Romania and Belarus throughout the entire post-communist period, and on this narrow base, to build a theoretical model that integrates Macedonia as an intermediate regime on stage two. Unfortunately, this cannot be done given the narrow base that applies to both Romania and Belarus before the mid-1990s. It will look as if empirical reality is forced to fit within some predesigned theoretical model. Another possible answer, again unacceptable, may be to give up any attempt to produce cross-case explanation, and to acknowledge that post-communist political regime diversity is in fact a problem that defies 
comparative analysis. In other words, this will mean to acknowledge that there are no common patterns across post-communist countries.

A tentative solution, away from both theoretical narrowness and total pessimism, is acknowledging that across different countries some common explanation is indeed possible, but that the independent variables that the literature already provides can still work much better on post-communist sub-period that skips early transition.

Returning to the problems on stage one, we need to reassess the relative importance of all independent variables. Two main groups of variables, legacy and political leadership, are supposed to provide either a constant effect over time (legacy) or an immediate effect on political regimes despite legacy and institutional constraints (leadership). Comparing Romania and Belarus as examples of opposing post-communist trends after the mid-1990s requires eliminating these two groups of variables. These countries' drift in opposite directions is not gradual starting immediately with the post-communist transition, which is contrary to the logic of the legacy explanation. Political leadership in each of these two countries is also unable to explain the nature of political regime because it does not act against the logic of the institutional choice framework. Therefore, the political leadership explanation providing positive correlation, without contradicting the legacy or institutional explanations, is spurious.

Putting aside legacy and political leadership leaves two broad groups of variables, institutional choice and external influence. Some variables within each of these two models not only correlate well with both Romania and Belarus after the mid-1990s; some of them are also supposed to affect political development after a certain time lag, rather than immediately. This may be the key for beginning to explain divergent political regimes in post-communist countries after the mid1990s.

Two institutional choice variables, the constitutional separation of powers and the electoral system for the legislature, and at least two external influence variables, EU/NATO membership expectations and leverage, are thus acting together in shifting political expectations and changing the cost-benefit calculation 
of the local political leadership. Separation of powers between legislative and executive within a parliament system of government leaves the government unable to independently impose authoritarian rules. Proportional representation leads to strong party representation, thus increasing legislative leverage vis-à-vis the government, which is checked politically by both parliament and by the party system. EU/NATO generate both expectations and leverage. In terms of expectations, they shift the rational choice of political leadership toward democratization; through active leverage they may impose new institutions producing similar political outcomes over time.

Comparing Romania and Belarus however makes external factors a much weaker explanation than institutional choice even if we assume that somehow they act in combination. Belarus is a country where EU/NATO have zero value as external factors, meaning that they leave other factors to play a predominant role in political development. From the above discussion, we see that these other factors cannot represent legacy or political leadership. Therefore, analysis on stage one, comparing two opposing trends, Romania and Belarus, leaves only a couple of good and common explanatory variables that produce political effects not immediately but with certain period of time after they are introduced. These variables are constitutional separation of powers and electoral system for parliament; they are both part of institutional choice model.

On stage two we introduce Macedonia as an example of intermediate regime. Before discussing this case it is worth mentioning one particularity. On both variables, constitutional separation of powers and electoral system for parliament, Macedonia tilts toward post-communist countries that are expected to democratize. This means that its intermediate status is not an autocracy that fails to materialize, but failed (hopefully only thus far!) democracy. This particularity is important in order to look not to all possible additional well-correlating variables, but only to such positive value variables that indicate a strong tilting toward authoritarian development. We are especially interested in variables that show a positive correlation with Macedonia, and a much weaker correlation with Romania as a case of democratization. If these variables are common to Macedonia and 
Romania then the question of why they do not produce a democratic backslide in Romania of similar magnitude will remain open and unsolved.

Variables that positively correlate to Macedonia's intermediate situation, but do not correlate to the Romanian case in general, or to sub-periods in the Romanian case, are clustered in two groups: legacy and external influence. Up to four external influence variables correlate positively to the Macedonian case for most of the 1990s: EU/NATO expectations, EU/NATO support, EU/NATO leverage, and strong authoritarian state influence. The weakness of these variables as explanations for Macedonia's intermediate status is that they all have zero or weak value during this sub-period. Variables included in the legacy model that correlate well to the Macedonian cases, such as elite strategy, party high echelon autonomy, and shared rulers/ruled identity, as well as the existence of a sovereign state from the institutional choice model, have, however, positive values.

These remaining four variables are independent from one another. For instance, main elite strategy under communism does not cause any of the other three variables, e.g. shared rulers/ruled identity, nor it is caused by any of them. The same conclusion applies to all four variables. Theoretically any of them, or all of them in combination, may bring about the failure of complete democratization in Macedonia. They are strong enough to keep the country in this position despite the pro-democratization effect of EU/NATO after the end of 1990s. Variables like elite strategy and party high echelon autonomy may however gradually erode as factors determining political development. As explanations they can clarify the early transitional period but can hardly influence mid- and long-term political development. A lack of shared identity between rulers and the ruled and a lack of indisputable state sovereignty, however, are much deeper legacy and institutional explanations. They are able to influence the political development of particular country for generations.

Thus most logical solution for explaining the intermediate case of Macedonia will be to look at some legacy and institutional factors, or a combination of both, that contradict the strong democratization logic of the constitutional separation of powers and an electoral system for legislature. External factors are 
still too weak to overcome legacy and institutional obstacles, but since the early 2000 s, they move Macedonia very slowly toward more political democracy.

This flexible two-stage explanation for post-communist political regime diversity is powerful in that it allows for broader generalization beyond the initial sample. Post-communist countries with initial intermediate status, according to Freedom House, later follow the same logic of development as the cases discussed in this project. Kazakhstan has a very strong and largely unaccountable presidential office from the beginning of transition, elected by the general population, and a weak 2-chamber parliament, of which members are elected or appointed using different techniques, with only tiny minority of them, approximately ten percent, representing political parties elected by proportional representation (Frye 1997; 2002; Ishiyama and Velten 1998; CIA 2006). With these institutional prerequisites we can expect that Kazakhstan will become an authoritarian political regime, which is in fact what happens.

On the other hand, Croatia, following our flexible model prediction, develops into a democratic political regime because of two main institutional ingredients, a political accountable executive within a system of separation of powers, and proportional representation in the legislature, which are present the from very beginning of transition (Ibid.). For this country, delay in democratization is obviously the result of exogenous factors like wars of secession in the former Yugoslavia. Once these factors are eliminated, institutional choice variables almost instantly produce a democratic political regime.

As for other intermediate regimes, e.g. Albania, Moldova, Armenia, and Georgia, we observe that variables that allow Macedonia to escape from either of the two political extremes: a deficit in state sovereignty and a lack of common identity between rulers and the ruled, are responsible for these countries' situation too. There are, however, significant differences between these intermediate political regimes. Albania and Moldova are parliamentary republics with mixed electoral systems or proportional representation, meaning that a deficit in sovereignty (Albania) and a lack of rulers/ruled common identity (Moldova) prevent these countries from complete democratization; on the other hand, Armenia and Georgia 
have strong presidential offices but use different electoral systems; in this case, a deficit in sovereignty (Armenia, Georgia) and a lack of rulers/ruled common identity (Georgia) explain failures of authoritarianism, rather than failures of democratization.

\subsection{Concluding remarks}

This chapter shows that it is impossible, hopefully only temporarily, given the variables provided by the literature so far, to offer a comprehensive rigid model for post-communist political development. Such a rigid model must satisfy at least two conditions; first, it must show positive correlation for some variables from one model or across models to all three cases. Second, it must also prove links of causality between these variables and all possible political outcomes. Analysis of the findings shows that there are no variables that satisfy both conditions. Therefore, a more flexible explanatory model is needed.

The flexible model presented in this chapter makes certain compromises without completely eliminating the possibility of theoretical explanation and empirical generalizability. It introduces a two-stage analysis, in which countries with opposing political trends are analyzed first and intermediate political regime is discussed later. This flexible model allows for the identification of variables that cause different political trends such as constitutional separation of powers and the type of electoral system, and also identification of other variables that may cause a mid-term slowdown in political development such as shared common identity between rulers and the ruled, and the existence of a sovereign state. This flexible model also identifies legacy and institutional variables as stronger compared to external influence. It allows for broader generalization including other postcommunist countries. 


\section{Conclusion}

This project starts with some dissatisfaction with current level of research explaining post-communist political regime diversity and ends with a tentative explanation for main post-communist political trends. It divides the literature analytically into four main approaches, looking for explanations based on legacies, post-communist institutional choices, transitional period political leadership, or the level of external influence and support. Its literature review goes beyond usual assessment as a necessary first step in each research. It also paves the way for the crafting of comparable explanatory models, without which this project would have easily become unmanageable in terms of time and space. Finding the best country cases representing different post-communist trajectories is the next logical step. This step allows the project to be reduced to the strict minimum of cases, which, however, are still capable of producing generalizations across the entire postcommunist world. Testing four comparable models on three cases representing major political trends creates a rich pool of findings that are analyzed in order to find best the explanation for post-communist regime diversity. Questions raised by applying generic models to different cases find their tentative answers in the end of this project. The need for theoretical rigidity, of a one-size-fits-all solution gradually retreats, replaced by a more flexible approach embracing variables from various models.

This project draws the following conclusions: First, none of the existing major analytical categories taken in a cluster is powerful enough to predict all the major trends of post-communist political regime diversity. Contrary to the highly optimist claims they advance, their cumulative predictions are either too inconclusive, or point in an entirely wrong direction. Second, 'unpacking' these analytical categories into a myriad of independent variables is no more helpful than taking them as clusters. Only a few of them correlate well with one or another postcommunist periods across all cases. None of these hypotheses is powerful enough to provide a rigid explanatory model for political regime diversity that goes beyond mere positive correlation, thus making the danger of spuriousness real. Third, some independent variables provided by the institutional choice approach, namely the 
constitutional separation of powers and electoral system for parliament, provide good correlation and explanation for opposing trends of political regime development, i.e. democracy and authoritarianism. Fourth, additional independent variables included in the legacy and institutional choice model, such as shared public identity between rulers and ruled, and the existence of a sovereign state, provide an additional insight as to the reason why certain post-communist countries still remain intermediate political regimes. Fifth, this new explanatory model is applicable mainly to post-communist development after the mid-1990s; it does not claim to provide a satisfactory explanation for trends occurring earlier during postcommunist transition.

Understanding post-communist political development and diversity is a gradual process, not an instant snapshot; new literature will hopefully provide additional theoretical models and with them, independent variables, within or outside existing schools. This may make further analysis more accurate and its conclusions more rigid. Any research provides at least tentative answers to existing questions, but also poses new questions thus making possible new research in this field. Questions that this project raises, in need of further explanations, are few, but significant. What exactly produces an initial intermediate political regime in so many post-communist countries? Is it due to the activity of one or many factors, or on the contrary, is it due to an inactivity of factors that can only influence a country moving toward democracy or authoritarianism? Why is it that factors that are good at explaining extreme political developments are not so good at explaining a persistent middle ground situation? Is there only one type of intermediate regime, or what we see as intermediate regime indeed represents two separate groups, failed democracies and failed authoritarianisms accidentally only having equal scores on the scale of freedoms? Model generalization, as seen in previous chapter, so far tilts toward assuming that there are indeed two different types of intermediate regimes, but a final answer to this question requires additional research. A much more fundamental epistemological question, existing far before this project and still without a clear answer, is whether we can compare countries that may live in different historical times only because they happen to experience a comparatively 
brief period of uniform political regime, namely communism? Is this period such a clear watershed that it renders countries with very different historical backgrounds sufficiently uniform and capable of further comparison? This project assumes that the answer to this question is affirmative, but further research may prove the opposite.

The social sciences' interest in understanding post-communist countries' political transformation and their possible democratization goes far beyond the group of current post-communist nations, for some of which the process of democratization is firmly an issue of the past. It is not part of their everyday political life but rather part of their history. Some countries in the world however still remain communist as far as their political system is concerned, not to mention tens of countries with various forms of undemocratic or unconsolidated political regimes. Some of these undemocratic polities are former communist states. Still unable to predict the speed, direction or starting moment of their future postauthoritarian political transformations, we may use the lessons accumulated during the 1989-2006 experience in Central and Eastern Europe and the former USSR in order to get prepared with range of possible expectations and a menu of political suggestions making these post-authoritarian transitions smoother and hopefully irreversible. This makes the research of causes for post-communist political regime diversity an area with a promising future as a sub-field of comparative democratization studies. 


\section{References}

Ackerman, Bruce. 1992. The Future of Liberal Revolution. New Haven and London: Yale University Press.

Ackermann, Alice. 2000. Making peace prevail: Preventing violent conflict in Macedonia. Syracuse: Syracuse University Press.

Agh, Attila. 1999. Process of democratization in the East Central European and Balkan states. Communist and Post-communist Studies 32.

Agopsowitcz, Monika and James Landon. 1995. Promoting Pluralism in Eastern Europe. Journal of Democracy 6(4).

Barany, Zoltan. 1997. Democratic Consolidation and the Military: The East European Experience. Comparative Politics 30(1).

Barany, Zoltan. 2004. NATO's Peaceful Advance. Journal of Democracy 15(1).

Barany, Zoltan. 2005. "Ethnic Mobilization in the Postcommunist Context: Albanians in Macedonia and the East European Roma". in Zoltan Barany and Robert G. Moser, eds. Ethnic Politics After Communism. Ithaca and London: Cornell University Press.

Bideleux, Robert. 2001. "Europeanisation' and the limits to democratization in East-Central Europe". in Geoffrey Pridham and Attila Agh, eds. Prospects for democratic consolidation in East-Central Europe. Manchester and New York: Manchester University Press.

Brown, Archie. 2001. Ten Years After the Soviet Breakup: From Democratization to 'Guided Democracy'. Journal of Democracy 12(4).

Brown, Archie. 2002. "From Democratization to 'Guided Democracy"'. in Larry Diamond and Marc F. Plattner, eds. Democracy after Communism. Baltimore and London: The Johns Hopkins University Press.

Brzezinski, Zbigniew. 2002. "The Primacy of History and Culture". in Larry Diamond and Marc F. Plattner, eds. Democracy after Communism. Baltimore and London: The Johns Hopkins University Press.

Bunce, Valerie. 2003. Rethinking Recent Democratization: Lessons from the Postcommunist Experience. World Politics 55(2). 
Bunce, Valerie. 2004. “Comparative Democratization: Lessons from Russia and the Postcommunist World". in Michael McFaul and Kathryn Stoner-Weiss, eds. After the Collapse of Communism. Comparative Lessons of Transition. Cambridge: Cambridge University Press.

Carothers, Thomas. 1996. Romania: Projecting the Positive. Current History 95.

Chiriac, Marian. 2001. Deadlocked Romania. Current History 100.

Chirot, Daniel. 2005. "What provokes violent ethnic conflict? Political choice in one African and two Balkan cases". in Zoltan Barany and Robert G. Moser, eds. Ethnic Politics After Communism. Ithaca and London: Cornell University Press.

Chouchkevitch, Stanislav. 2005. "Le Belarus. Preface (Belarus. Preface)". in Francois Depelteau and Aurelie Lacassagne, eds. Le Belarus: L'Etat de L'exception (Belarus: Exceptional state). Quebec: Universite Laval.

CIA. 2006. CIA - The World Factbook. Available online at: https://www.cia.gov/cia/publications/factbook/index.html

Colton, Timothy. 2004. "Parties, Citizens, and the Prospects for Democratic Consolidation in Russia". in Michael McFaul and Kathryn Stoner-Weiss, eds. After the Collapse of Communism. Comparative Lessons of Transition. Cambridge: Cambridge University Press.

Colton, Timothy, and Cindy Skach. 2005. The Russian Predicament. Journal of Democracy 16(3).

Crawford, Beverly and Arend Lijhart. 1997. "Old Legacies, New Institutions: Explaining Political and Economic Trajectories in Post-Communist Regimes". in Bewerly Crawford and Arend Lijhart, eds. Liberalization and Leninist Legacies. Comparative Perspectives on Democratic Transition. Berkeley, CA: University of California Press.

Curry, Jane. 1995. "The Sociological Legacies of Communism". in Zoltan Barany and Ivan Volgyes, eds. The Legacies of Communism in Easter Europe. Baltimore and London: The Johns Hopkins University Press.

Dostal, Petr and Jan Markusse. 2004. "La geographie de l'opinion publique a propos de l'integration europeenne (Geography of public opinion vis-a-vis European integration)". in Yann Richard and Adre-Louis Sanguin. L'Europe de l'est. Quinze ans apres la shute du mur (Eastern Europe. Fifteen Years After Fall of the Wall). Paris: L'Harmattan. 
Downs, W.M. and R.V.Miller. 2005. The 2004 presidential and parliamentary elections in Romania. Electoral Studies 24.

Duhamel, Luc. 2005. "Loukachenko, La Bielorussie et la Russie (Loukashenko, Belarus and Russia)". in Francois Depelteau and Aurelie Lacassagne, eds. Le Belarus: L'Etat de L'exception (Belarus: Exceptional state). Quebec: Universite Laval.

Ekiert, Grzegorz. 2003. "Patterns of Postcommunist Transformation in Central and Eastern Europe". in Grzegorz Ekiert and Stephen E. Hanson, eds. Capitalism and Democracy in Central and Eastern Europe. Assessing the Legacy of Communist Rule. Cambridge: Cambridge University Press.

Elster, Jon, Claus Offe, and Ulrich K. Preuss. 1998. Institutional Design in PostCommunist Societies. Rebuilding the Ship at Sea. Cambridge: Cambridge University Press.

Fish, M. Steven. 1997. The pitfalls of Russian superpresidentialism. Current History 96(612).

Fish, M. Steven. 2001. "The Dynamics of Democratic Erosion". in Richard D. Anderson, Jr., M. Steven Fish, Stephen E. Hanson, and Philip G. Roeder. Postcommunism and the Theory of Democracy. Princeton and Oxford : Princeton University Press.

Fish, M. Steven. 2002. "Putin's Path". in Larry Diamond and Marc F. Plattner, eds. Democracy after Communism. Baltimore and London: The Johns Hopkins University Press.

Freedom House Organization. 2005. "Nations in Transit". Available online at: http://www.freedomhouse.org/

Freedom House Organization. 2006. "Freedom in the World Comparative Ranking: 1973-2005". Available on: http://www.freedomhouse.org/

Frye, Timothy. 1997. A Politics of Institutional Choice: Post-Communist Presidencies. Comparative Political Studies 30(5).

Frye, Timothy. 2002. "Presidents, Parliaments, and Democracy: Insights from the Post-Communist World". in Andrew Reynolds, ed. The Architecture of Democracy. Constitutional Design, Conflict Management, and Democracy. Oxford: Oxford University Press.

Gallagher, Tom. 1995. Romania after Ceausescu: The Politics of Intolerance. Edinburgh: Edinburgh University Press. 
Gallagher, Tom. 2005a. Theft of a Nation. Romania since Communism. London : Hurst \& Company.

Gallagher, Tom. 2005b. Modern Romania: The End of Communism, the Failure of Democratic Reform, and the Theft of a Nation. New York : New York University Press.

Gallagher, Tom. 2005c. The Balkans in the New Millennium. London and New York: Routeledge.

Geddes, Barbara. 1995. A Comparative Perspective on the Leninist Legacy in Eastern Europe. Comparative Political Studies 28(2).

Geddes, Barbara. 1997. "A Comparative Perspective on the Leninist Legacy in Eastern Europe". in Beverly Crawford and Arend Lijhart, eds. Liberalization and Leninist Legacies. Comparative Perspectives on Democratic Transition. Berkeley, CA: University of California Press.

Gilberg, Trond. 1990. Romania: Will History Repeat Itself? Current History 89.

Grzymala-Busse, Anna. 2002a. Redeeming the Communist Past. The Regeneration of Communist Parties in East Central Europe. Cambridge: Cambridge University Press.

Grzymala-Busse, Anna. 2002b. The programmatic turnaround of communist successor parties in East Central Europe 1989-1998. Communist and PostCommunist Studies 35(1).

Grzymala-Busse, Anna. 2003a. "Redeeming the Past: Communist Successor Parties after 1989". in Grzegorz Ekiert and Stephen E. Hanson, eds. Capitalism and Democracy in Central and Eastern Europe. Assessing the Legacy of Communist Rule. Cambridge: Cambridge University Press.

Grzymala-Busse, Anna, and Abby Innes. 2003b. Great Expectations: The EU and Domestic Political Competition in East Central Europe. East-European Politics and Societies 17(1).

Grzymala-Busse, Anna. 2006. Authoritarian Determinants of Democratic Party Competition: The Communist Successor Parties in East Central Europe. Party Politics 12(3).

Hanson, Stephen. 1995. The Leninist Legacy and Institutional Change. Comparative Political Studies. 28(2).

Hanson, Stephen. 1997. "The Leninist Legacy, Institutional Change, and PostSoviet Russia". in Bewerly Crawford and Arend Lijhart, eds. Liberalization 
and Leninist Legacies. Comparative Perspectives on Democratic Transition. Berkeley, CA: University of California Press.

Higley, John, Judith Kullberg, and Jan Pakulski. 1996. The Persistence of Postcommunist Elites. Journal of Democracy 7(2).

Higley, John, Judith Kullberg, and Jan Pakulski. 2002. “The Persistence of Postcommunist Elites". in Larry Diamond and Marc F. Plattner, eds. Democracy after Communism. Baltimore and London: The Johns Hopkins University Press.

Hislope, Robert. 2004. Crime and Honor in a Weak State. Problems of PostCommunism 51(3).

ICG Balkans Report. 1998. "1998 Elections in Macedonia". ICG Balkans Report 45. Skopje-Sarajevo.

ICG Balkans Report. 1999. "Macedonia: New Faces in Skopje". ICG Balkans Report 51. Skopje-Brussels.

IISEPS. 2006. "Независимый институт социально-экономических и холитических исследований (Independent Institute for Socio-Economic and Political Studies)". Available online in Russian at: http://www.iiseps.org/1205-07.html

Ishiyama, John T., and Matthew Velten. 1998. Presidential Power and Democratic Development in Post-Communist Politics. Communist and Post-Communist Studies 31(3).

Johnson, Juliet. 2003. “"Past' Dependence or Path Contingency? Institutional Design in Postcommunist Financial Systems." in Grzegorz Ekiert and Stephen E. Hanson, eds. Capitalism and Democracy in Central and Eastern Europe. Assessing the Legacy of Communist Rule. Cambridge: Cambridge University Press.

Jowitt, Ken. 1992. New World Disorder: The Leninist Extinction. Berkeley, Los Angeles, Oxford: University of California Press.

Kitschelt, Herbert, Zdenka Mansfeldova, Radoslaw Markowski, and Gabor Toka. 1999. Post-Communist Party Systems. Competition, Representation, and Inter-Party Cooperation. Cambridge: Cambridge University Press.

Kitschelt, Herbert. 2003. "Accounting for Post-Communist Regime Diversity. What Counts as a Good Cause?" in Grzegorz Ekiert and Stephen E. Hanson, eds. Capitalism and Democracy in Central and Eastern Europe. Assessing the Legacy of Communist Rule. Cambridge: Cambridge University Press. 
Kolarska-Bobnska, Lena. 2003. The EU Accession and Strengthening of Institutions in East Central Europe: The Case of Poland. East-European Politics and Societies 17(1).

Kopstein, Jeffrey and Mark Lichbach, ed. 2005. Comparative Politics: Interests, Identities, and Institutions in a Changing Global Order, $2^{\text {nd }}$ ed. Cambridge : CUP.

Kopstein, Jeffrey S., and David A. Reilly. 2003. "Postcommunist Spaces: A Political Geography Approach to Explaining Postcommunist Outcomes". in Grzegorz Ekiert and Stephen E. Hanson, eds. Capitalism and Democracy in Central and Eastern Europe. Assessing the Legacy of Communist Rule. Cambridge: Cambridge University Press.

Lahviniec, Alaksandr. 2005. "Orient ou Occident (East or West)". in Francois Depelteau and Aurelie Lacassagne, eds. Le Belarus: L'Etat de L'exception (Belarus: Exceptional state). Quebec: Universite Laval.

Levintova, Ekaterina. 2006. Revisiting Russian and Polish elite value orientation. Communist and Post-Communist studies 39.

Levitsky, Steven, and Lucan A. Way. 2005a. International Linkage and Democratization. Journal of Democracy 16(3).

Levitsky, Steven, and Lucan A. Way. 2005b. Ties That Bind? Leverage, Linkage, and Democratization in the Post-Cold War World. International Studies Review 7(3).

Linz, Juan J. 1990. The Perils of Presidentialism. Journal of Democracy 1(1).

Linz, Juan J., and Alfred Stepan. 1996. Problems of Democratic Transition and Consolidation. Southern Europe, South America, and Post-Communist Europe. Baltimore and London: The Johns Hopkins University Press.

Marples, David R. 1999. Belarus: Denationalized Nation. Amsterdam: Harwood Academic Publishers.

McFaul, Michael. 2001. Ten Years After the Soviet Breakup: A Mixed Record, An Uncertain Future. Journal of Democracy 12(4).

McFaul, Michael. 2002. The Fourth Wave of Democracy and Dictatorship. Noncooperative Transitions in the Post-communist World. World Politics 54(2). 
McFaul, Michael. 2004. "A Mixed Record, and Uncertain Future". in Larry Diamond and Marc F. Plattner, eds. Democracy after Communism. Baltimore and London: The Johns Hopkins University Press.

McFaul, Michael. 2005. Transitions from Postcommunism. Journal of Democracy $16(3)$.

Mihut, Liliana. 1994. The Emergence of Political Pluralism in Romania. Communist and Post-Communist Studies 27(4).

Mot, Anca-Elena. 2002. Le passage du socialisme aux capitalismes. Determinants socio-historiques des trajectoires polonaise et roumaine (Transition from socialism to capitalisms. Socio-historic causes for Polish and Romanian trajectories). $\mathrm{PhD}$ dissertation. Montreal: University of Montreal.

Mungiu-Pippidi, Alina. 2004. The Unbearable Lightness of Democracy : Poland and Romania after Communism. Current History 103.

Nelson, Daniel N. 1990. Romania. Electoral Studies 9(4).

Nelson, Daniel N. 1995. "Romania". in Zoltan Barany and Ivan Volgyes, eds. The Legacies of Communism in Easter Europe. Baltimore and London: The Johns Hopkins University Press.

Nodia, Ghia. 2002. "How Different Are Postcommunist Transitions?" in Larry Diamond and Marc F. Plattner, eds. Democracy after Communism. Baltimore and London: The Johns Hopkins University Press.

Norris, Pippa. 2002. "Ballots Not Bullets: Testing Consociational Theories of Ethnic Conflict, Electoral Systems, and Democratization". in Andrew Reynolds, ed. The Architecture of Democracy. Constitutional Design, Conflict Management, and Democracy. Oxford: Oxford University Press.

Pankovski, Serguei, and Jean Markou. 2005. "Le phenomene bielorusse (Belarussian phenomenon)". in Francois Depelteau and Aurelie Lacassagne, eds. Le Belarus: L'Etat de L'exception (Belarus: Exceptional state). Quebec: Universite Laval.

Perry, Duncan. 1996. Macedonia: Balkan Miracle or Balkan Disaster? Current History 95.

Perry, Duncan. 2000. Macedonia's Quest for Security and Stability. Current History 99.

Phillips, John. 2004. Macedonia: Warlords and Rebels in the Balkans. New Haven and London: Yale University Press. 
Pridham, Geoffrey. 2001. "Rethinking regime-change theory and the international dimension of democratization: ten years after in East-Central Europe". in Geoffrey Pridham and Attila Agh, eds. Prospects for democratic consolidation in East-Central Europe. Manchester and New York: Manchester University Press.

Pridham, Geoffrey. 2005. Designing Democracy: EU Enlargement and Regime Change in Post-Communist Europe. London and New York: Palgrave Macmillan.

Popescu, Marina. 2003. The Parliamentary and presidential elections in Romania, November 2000. Electoral Studies 22.

Raik, Kristi. 2004. EU Accession of Central and Eastern European Countries: Democracy and Integration as Conflicting Logics. East-European Politics and Societies 18(4).

Ratesh, Nestor. 1993. Romania: Slamming on the Brakes. Current History 92.

Richard, Yann. 2004. "La Bielorussie post-sovietique. Un nouvel espace? ("PostSoviet Belarus. A new space?")" in Yann Richard and Adre-Louis Sanguin. L'Europe de l'est. Quinze ans apres la shute du mur (Eastern Europe. Fifteen Years After Fall of the Wall). Paris: L'Harmattan.

Roeder, Philip G. 1994. Varieties of Post-Soviet Authoritarian Regimes. Post-Soviet Affairs 10(1).

Roeder, Philip G. 2001. "The Rejection of Authoritarianism". in Richard D. Anderson, Jr., M. Steven Fish, Stephen E. Hanson, and Philip G. Roeder. Postcommunism and the Theory of Democracy. Princeton and Oxford : Princeton University Press.

Sabates-Wheeler, Rachel. 2001. Land Reform and Farm Choice in Romania. Problems of Post-Communism 48(4).

Schopflin, George. 1993. Politics in Eastern Europe: 1945-1992. Oxford, UK, Cambridge, MA: Blackwell.

Shugart, Matthew S. 1997. "Politicians, Parties, and Presidents: An Exploration of Post-Authoritarian Institutional Design". in Beverly Crawford and Arend Lijhart, eds. Liberalization and Leninist Legacies. Comparative Perspectives on Democratic Transition. Berkeley, CA: University of California Press.

Shvetsova, Olga. 1999. A survey of post-communist electoral institutions: 19901998. Electoral Studies 18. 
Shvetsova, Olga. 2002. "Institutions and Coalition-Building in Post-Communist Transitions". in Andrew Reynolds, ed. The Architecture of Democracy. Constitutional Design, Conflict Management, and Democracy. Oxford: Oxford University Press.

Siani-Davies, Peter. 1996. Romanian Revolution or Coup d'etat? Communist and Post-Communist Studies 29(4).

Slitski, Vitali. 2005. "De l'independence a Loukachenko (From Independence to Lukashenko)". in Francois Depelteau and Aurelie Lacassagne, eds. Le Belarus: L'Etat de L'exception (Belarus: Exceptional state). Quebec: Universite Laval.

Stroschein, Sherill. 2001. Measuring Ethnic Party Success in Romania, Slovakia, and Ukraine. Problems of Post-Communism 48(4).

USAID. 2006. "National Poll Finds Economic Issues Top List of Citizen Concerns". Available online at: http://www.usaid.org.mk/

Vachudova, Milada Anna. 2005. Europe Undivided: Democracy, Leverage, and Integration After Communism. Oxford : Oxford University Press.

Volgyes, Ivan. 1995. "The Legacies of Communism: An Introductory Essay"; "The Economic Legacies of Communism". in Zoltan Barany and Ivan Volgyes, eds. The Legacies of Communism in Easter Europe. Baltimore and London: The Johns Hopkins University Press.

Way, Lucan A. 2005. Authoritarian State Building and the Sources of Regime Competitiveness in the Fourth Wave. World Politics 57(2). 